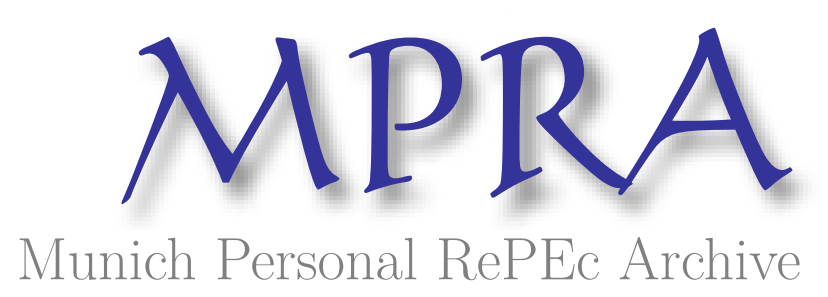

\title{
Oil Price Shocks, Firm Uncertainty and Investment
}

Lee, Kiseok and Kang, Wensheng and Ratti, Ronald A.

Kyung Hee University, Kent State University, University of Western Sydney

1 September 2010

Online at https://mpra.ub.uni-muenchen.de/49044/

MPRA Paper No. 49044, posted 13 Aug 2013 07:49 UTC 


\title{
Oil Price Shocks, Firm Uncertainty and Investment
}

\author{
by \\ Kiseok Lee ${ }^{\mathbf{a}}$, Wensheng Kang ${ }^{\mathbf{b}}$, Ronald A. Ratti, ${ }^{\mathbf{c}}$ * \\ a Department of Economics, Kyung Hee University, Seoul, Korea, \\ ${ }^{\mathbf{b}}$ Department of Economics, Kent State University, New Philadelphia, Ohio, USA \\ ${ }^{\mathbf{c}}$ School of Economics and Finance, University of Western Sydney, NSW, Australia
}

\begin{abstract}
It is found that an oil price shock in interaction with a firm's stock price volatility has a negative effect on investment by that firm, both in the short and long-term. In the presence of this interaction term, linear variables in oil price shocks are not statistically significant. There is evidence that for the short-term effects of the interaction variable, the particular magnitude of an oil price shock may not be as important as the fact that there is an oil price shock. For the longterm effects, however, the magnitude of the oil price shock does matter. Over a longer horizon, oil price shocks depress investment more at firms facing greater uncertainty. An increase in firm stock price volatility continues to reduce the link between sales growth and investment in the presence of oil price shocks as in Bloom et al. (2007).
\end{abstract}

September 2010

Key words: Oil price shocks, firm uncertainty, stock price volatility, investment

JEL Classification: E22, G31, Q43

*Corresponding author.

E-mail address: r.ratti@uws.edu.au 


\section{Oil Price Shocks, Firm Uncertainty and Investment}

\section{Introduction}

The literature on the relationship between oil price shocks and economic and financial activity has grown quite large in recent years and has covered a number of issues. Early papers by Hamilton (1988), Mork (1989), Lee, Ni, and Ratti (1995), Hooker (1996), among others, report a negative association between oil price shocks and economic activity. Papers by Kilian (2008a, 2008b, 2009b) and Kilian and Park (2009) argue that the size of the impact of oil price shock on economic activity differs by the source of the oil shock, and Fukunaga, Hirakata, and Sudo (2010) finds that the character of these effects differ across countries. A number of papers find that large oil price movements have significant impact on major macroeconomic variables such as GDP, inflation, and productivity (see, for instance, Barsky and Kilian (2002, 2004)). Hamilton (2005) argues that nine out of ten U.S. recessions that occurred between 1948 and 2001 were preceded by a substantial increase in the oil price. Engemann, Kliesen, and Owyang (2010) find that oil price shocks significantly increase the probability of recessions in a number of countries. Recent papers by Rahman and Serletis (2010) and Elder and Serletis (2010) examine the impact of oil price shocks on aggregate uncertainty and find that the oil price shocks have significantly negative effects on investment, durables consumption and aggregate output.

The transmission mechanism by which oil price shocks affect economic activity has also been a focus for research. Edelstein and Kilian (2007b) argue that oil price shocks may affect nonresidential fixed investment through either a 'supply channel' in which an increase in the cost of production driven by an increase in real oil prices decreases production, or a 'demand channel' in which consumer spending falls in response to rising energy prices. Lee and $\mathrm{Ni}$ (2002) in

analysis of U.S. sectoral output provide evidence that oil price shocks work not through a supply 
channel but by a demand channel. In an investigation of the effects of oil price shocks on stock returns, Kilian and Park (2009) argue oil shocks affect the macroeconomy through changes in the final demand for goods and services. Gogineni (2009) finds that the extent to which stock returns are negatively affected by oil price changes depends largely on the nature of the industry.

Advocates of the view that oil price shocks significantly influence the economy have always been confronted by the fact that the share of oil use in the U.S. GDP is quite small. The share of energy use in nominal GDP has been below four percent since 1983 and that of crude oil has been much smaller. ${ }^{1}$ In addition, sometimes a surge in the real oil price is accompanied by a robust growth in GDP. Recent data suggest that both the real price of oil and GDP rose persistently during 2003-08. ${ }^{2}$ When the world economy collapsed in the late 2008 as a result of the financial crisis, so did the real oil price. The positive co-movement in the real price of oil and real GDP cannot be explained by shifts in the supply curve driven by the rise in production costs and/or the decline in productivity.

In this paper we wish to build on related strands in the literature that focus on investment decisions by firms. The intuition in our approach is that an oil price shock has a greater effect on delaying a firm's investment the greater the uncertainty faced by that firm. In well-known papers Bernanke (1983) and Pindyck (1991) argue that changes in energy prices create uncertainty about future energy prices, causing firms to postpone irreversible investment decisions. This channel is consistent with firms reacting not only to the uncertainty about future production costs but also to the uncertainty about future sales. The other strand in the literature represents the view advanced by Leahy and Whited (1996), Bloom (2007), Bloom, Bond and Van Reenen

\footnotetext{
1 There were only three years, 1980, 1981, and 1982, since 1979 in which energy use in nominal GDP exceeded four percent. See, for instance, Kilian (2007).

${ }^{2}$ Kilian (2009b) claims that the surge in the real price of oil during 2003-08 is caused by fluctuations in the global business cycle, driven mainly by unexpected growth in emerging Asia superimposed on strong growth in the OECD.
} 
(2007) that uncertainty faced by the individual firm can be represented by its own stock price volatility. Bloom et al. (2007) regard firm stock price volatility and sales growth as being jointly determined by market forces and as being important influences for firm investment decisions.

This paper examines the effect of real oil price shocks on firm level investment, both directly and in interaction with firm stock price volatility and with firm sales growth. ${ }^{3}$ A dynamic firm-level investment equation with data on over 3,000 U.S. manufacturing firms for 1962-2006 is estimated. The focus on firm data is in itself interesting since most work on the influence of oil price shocks examines fairly aggregate economic and financial data. Firms are different in terms of both the intensity of the use of oil related products and the responsiveness of their clients' to oil price shocks. Various non-linear transformations of the growth rate of real oil price are shown to affect firm investment significantly in the long-run. The results suggest that oil price shocks influence firm investment and that the interaction of oil price shocks with firm stock price volatility is dominant in effect. The negative effect of an oil price shock on a firm's investment is larger in absolute value the larger is a firm's stock price volatility, both in the short and in the long-term. In the presence of interaction terms between oil price shocks and firm stock price volatility, an oil price shock on its own is not statistically significant. An increase in firm stock price volatility continues to reduce the link between sales growth and investment as suggested by Bloom et al. (2007) and this relationship is not significantly altered by oil price shocks.

Interestingly, an indicator function, that takes value 1 if a Hamilton (1996) type oil price

\footnotetext{
3 An associated literature has linked oil price shocks to stock returns. Huang, Masulis, and Stoll (1996) provide evidence of significant causality running from oil future prices to stock returns of individual firms. Jones and Kaul (1996) investigate whether oil price shocks trigger the movements of international stock markets and the movements can be justified by future cash flows changes. Sadorsky (1999) presents evidence that an oil price shock has a statistically significant negative effect on stock returns. Dreisprong, Jacobsen, and Maat (2008) report that oil price changes predict stock prices in 12 of the 18 developed economies and also in many emerging economies. Pollet (2004) presents evidence that expected changes in oil prices have forecast power for excess market returns as well as excess returns of most U.S. industries.
} 
shock is positive and 0 otherwise, is also found to perform well and to give results similar to a Hamilton (1996) type oil price shock variable itself. The empirical results indicate that for the short-term effects of the oil price shock/uncertainty variable, the particular magnitude of an oil price shock may not be important in determining investment by that firm. What is important is the fact that there is an oil price shock. For the long-term effects, however, the magnitude of the oil price shock does matter, with a larger oil price shock in interaction with a firm's stock price volatility having a larger depressing effect on that firm's investment. An increase in firm stock price volatility continues to reduce the link between sales growth and investment in the presence of oil price shocks as in Bloom et al. (2007). In line with this discussion it is apparent that oil price shocks depress investment more at firms facing greater uncertainty (indicated by firm stock price volatility) than at firms facing less uncertainty.

The paper proceeds as follows. The pattern of oil price shocks since 1971 will be briefly discussed in section 2. A firm's oil price shock variable is defined in section 3. The data and variables are described in section 4. Section 5 presents the empirical model and results and section 6 concludes.

\section{Observations on oil price shocks}

Most oil price shock dates coincided with the dates of geopolitical crises such as the October (Yom Kippur) War in October 1973 and the Arab oil embargo that followed, the Iranian Revolution in January 1979, the eruption of Iran-Iraq War in September 1980, the Iraqi invasion of Kuwait in August 1990 and the Gulf War that followed, the Afghan War in October 2001, and the Iraq War in March 2003. The patterns of real oil price movements differ greatly following these major geopolitical events. Figure 1 shows the real oil price movements and the vertical 
lines indicate the timing of the outbreak of the six major historical events. The October War in October 1973 and Gulf War in August 1990 are marked by sharp increases of oil price immediately following the wars. Oil price jumped 25 percent and 48 percent after the October War and the Gulf War, respectively. The Iranian Revolution triggered a persistent rise in oil price. Oil price increased continuously for almost two years after the revolution. The Iran-Iraq War in September 1980 witnessed a temporary increase followed by a persistent decline in oil price. The real oil price reached 45 dollars per barrel shortly after the war but started a process of five year decline ultimately reaching 10 dollars per barrel. After the breakout of Afghan War in October 2001 real oil price dropped for three consecutive months, but after four months, price began to rise significantly. Also, after the eruption of the Iraq War, the oil price decreased consecutively for two months. A possible reason for the decrease is the expectation that the U.S. would have improved access to the Iraqi oil reserves after the war.

Shocks to the flow demand of oil associated with the global business cycle are claimed to be responsible for oil price fluctuations in 1973/74, 1979/89, and the persistent rise during 20032008. On the other hand, the forward-looking oil traders' speculative demand for oil is responsible for sudden changes in oil price in 1979 (following the Iranian revolution), in 1986 (following the collapse of OPEC), in 1990/91 (following the invasion of Kuwait), 1997-2000 (following the Asian crisis), and in late 2008 (during the global financial crisis). ${ }^{4}$ Some of the years identified by demand channel advocates are also years marked by well-known geopolitical crises such as the October War in 1973 and the ensuing oil embargo, Iranian Revolution in 1979, Iran-Iraq War in 1980, Gulf War in 1990, and Iraq War in 2003. The geopolitical crises had immediate impact to the real price of crude oil either by embargo or by disturbances in the crude

\footnotetext{
4 See Kilian (2009b) for detailed discussion.
} 
oil supply channel.

Figure 2 illustrates the growth rate of the real crude oil price in which four out of six geopolitical events were followed immediately by sharp rises in real oil price. The last two events, the Afghan War and the Iraq War, are not followed by rises in real oil price. The October War in 1973 was followed by 18.9 percent rise in crude oil price in January 1974 and 25.0 percent rise in February 1974. After the Iranian Revolution in 1979 real oil price increased by 48.8 percent during nine months following the Revolution. The Iran-Iraq War was accompanied by a short-lived price rise. During the first three months of the Gulf War the crude price increased by 55.5 percent. Figure 2 also reveals that the volatility of the oil price growth has increased significantly since the collapse of OPEC cartel in the early 1986. The collapse of OPEC was accompanied by a more than 30 percent drop in the real price of oil. Since then the variability in the oil price growth rate increased sharply.

When war broke out in the Middle East the supply of crude oil was interrupted and the price of oil rose sharply. However, the sharp rise in oil price may not be considered as the main factor that drives down economic activity since the share of oil use in GDP is small. Instead, the uncertainty about the future path of the macroeconomy in the wake of war may be the main factor that shrinks the overall economic activity. A Middle East military conflict drives up the price of oil as well as the level of uncertainty about the future course of the economy. Regardless of the size of the oil or energy sectors in the GDP, oil price shocks may play the role of a proxy for major geopolitical events and hence be responsible for a downturn in economic activity.

\section{Firm's oil price shock/stock price volatility variable}

Bloom et al. (2007) regard the within-year standard deviation of stock returns for a firm as 
measuring the uncertainty from all sources confronting the firm at the time it makes decisions. It is descriptive of the environment for the firm at the time decisions are made. In the Bloom et al. (2007) model the level of sales and within-year standard deviation of stock returns as being jointly determined. We are interested in how oil price shocks in interaction with a firm's uncertainty level influences firm investment decisions. Since the finding of asymmetric effects of oil price on GDP growth by Mork (1989), nonlinear transformations of oil price have been suggested as shocks in the price of oil. Hamilton (1996) proposed the net oil price increase (NOPI) variable that is obtained by subtracting the maximum oil price of the last four quarters from current oil price if it is positive and zero otherwise. Two measures of oil price shocks similar to the Hamilton (1996) measure of oil price shocks will be constructed in this paper.

Following Barsky and Kilian (2002) and Kilian (2009a) data on the real oil price of oil are obtained by vertically concatenating two series, the refiner acquisition cost of imported crude oil (from the U.S. Department of Energy) for January 1974 to December 2007 and the PPI-oil for January 1962 to December 1973, deflated using the U.S. CPI.

A real oil price shock variable at time $t$ is defined as the growth rate in the real price of oil if the growth rate at that time is larger than growth rates that over the last twelve time periods:

$$
\begin{aligned}
\operatorname{pgmax}(12)_{t} & =p g_{t} \text { if } p g_{t}>\max \left(p g_{t-1}, p g_{t-2}, \ldots, p g_{t-12}\right) \\
& =0 \text { otherwise }
\end{aligned}
$$

where $p g_{t}$ denotes the growth rate of real oil price. $\operatorname{pgmax}(12)_{t}$ filters out relatively small increases in the real price oil and is based on and similar in spirit to Hamilton's (1996) net oil price increase. Net oil price introduced by Hamilton (1996) is meant to capture how disquieting an increase in the price of oil is for spending decisions of firms and consumers. The equivalent Hamilton measure would be $N O P I(12)_{t}=\max \left\{0, p_{t}-\max \left\{p_{t-1}, p_{t-2}, \ldots, p_{t-12}\right\}\right\}$ where 
$p_{t}$ is $\log$ real oil price. If real oil price is rising steadily, the Hamilton measure will yield a series of oil price shocks, whereas the use of price changes would not. ${ }^{5}$

We use two different ways of mapping oil price shocks into firm-level measure of oil price shock/uncertainty. The first measure of oil price shock/uncertainty of firm $i, U(12)_{i t}$, is defined as

$$
U(12)_{i t}=\operatorname{pgmax}(12)_{t} \cdot s_{i t}
$$

where $s_{i t}$ denotes the measure of firm $i$ 's standard deviation (volatility) of daily stock returns of the past 12 months (Baum, Caglaynan, and Talavera (2008)). For given $s_{i t}$ the oil price shock/uncertainty measure $U(12)_{i t}$ increases as the magnitude of oil price shock increases and hence the uncertainty faced by firm $i$ is allowed to reflect the size of oil price shock. Alternatively, for a given oil price shock, $U(12)_{i t}$ assumes a larger value the greater is $s_{i t}$, that is the greater the uncertainty confronting the firm. An aggregate counterpart to $U(12)_{i t}$ is given by

$$
U(12)_{t}=\operatorname{pgmax}(12)_{t} \cdot s_{t}
$$

where $s_{t}$ denotes the standard deviation of daily returns on the S\&P500 index for the past 12 months. Figure 4 illustrates the aggregate oil price shock/uncertainty measure given in equation (3). Following the October War, there was a significant rise in $U(12)_{t}$. After the Iranian Revolution and Iran-Iraq War, there were modest increases in $U(12)_{t}$. After the Gulf War, however, there was a huge increase in the aggregate oil price shock/uncertainty measure. This spike in $U(12)_{t}$ is due to the large increase in the real oil price and a significant increase in stock price volatility following the Gulf War as can be seen from a comparison of Figures 2 and 3. It seems that the Afghan War and the Iraq War were not associated with a rise in the aggregate

\footnotetext{
${ }^{5}$ Different time spans, such as 6 and 24 months, were also tried in our measure but the results were qualitatively the same.
} 
oil price shock/uncertainty variable.

The second oil price shock/uncertainty variable replaces $\operatorname{pgmax}(12)_{t}$ by the indicator function $\operatorname{pgmax}(12)_{t}^{01}$ such that the size of oil price shock does not affect the level of uncertainty faced by firm $i$. That is,

$$
U(12)_{i t}^{01}=\operatorname{pgmax}(12)_{t}^{01} \cdot s_{i t}
$$

where $\operatorname{pgmax}(12)_{t}^{01}$ is equal to 1 if $\operatorname{pgmax}(12)_{t}>0$ and 0 otherwise. The oil price shock/uncertainty measure $U(12)_{i t}^{01}$ represents the firm $i$ 's stock return volatility in the year of a positive oil price shock. Thus, in this case the magnitude of oil price shock/uncertainty variable for a firm is solely determined by its stock price volatility. The aggregate counterpart of this measure of $U(12)_{i t}^{01}$ can be obtained from

$$
U(12)_{t}^{01}=\operatorname{pgmax}(12)_{t}^{01} \cdot s_{t}
$$

where the individual firm's stock price volatility uncertainty $s_{i t}$ in equation (4) is substituted by the S\&P 500 index volatility $s_{\mathrm{t}}$. The time-series plot of $U(12)_{t}^{01}$ is in Figure 5. The plot shows somewhat different pattern in the size of aggregate oil price shock/uncertainty. In particular, the relative size of aggregate oil price shock/uncertainty following the Gulf War is significantly smaller than the one in Figure 4. However, the levels of aggregate oil price shock/uncertainty after the Iranian Revolution and Iran-Iraq War are greater than those in Figure 4.

\section{Data description and preliminary results}

\subsection{Data and variable specification}

The sample data come from three sources. The oil price is the monthly refiner acquisition cost (RAC) of imported crude oil as provided by the U.S. Department of Energy since January 1974. We extended the price series back to January 1962 and deflated the data 
using the U.S. CPI based on January 1983 dollars as in Barsky and Kilian (2002) and Killian (2007). ${ }^{6}$ The daily stock returns including dividends are from CRSP Daily Stock Combine File. The annual book value and other accounting data are from Standard and Poor's Industrial Annual COMPUSTAT database. The sample consists of an unbalanced panel of publicly traded manufacturing firms (SIC code 2000 - 3999) that spans from January 1962 to December 2007 drawn from the CRSP and COMPUSTAT databases.

We first compute the monthly growth rate of real oil prices and the monthly standard deviation of firm daily stock returns to generate all figures for the preliminary analysis. The annual growth rate of real oil price is the average of 12 monthly growth rates, and the annual stock price volatility is the average of 12 monthly volatilities. ${ }^{7}$ Negative observations of assets, sales, and capital stock in COMPUSTAT database are deleted because these observations are likely to be erroneous. Following Gilchrist and Himmelberg (1998) and Love (2003), we exclude stocks in the top and bottom $1 \%$ of the variable values. Observations with the values of the investment-to-capital, cash flow-to-capital, debt-to-capital ratios and Tobins' Q outside the 5-95 ${ }^{\text {th }}$ percentile range are excluded. We also exclude firms with missing, inconsistent data, or with less than 12 months of past return data. The final data set contains 3,322 firms and 69,113 firm-years.

Table 1 presents all variables used for data screening and model estimation in this paper. We utilize the daily stock returns to compute annual stock volatilities, denoted $s_{i t}$, for the firm $i$ in the fiscal year $t$ via the method proposed by Baum et al. (2008). ${ }^{8}$ The use of stock volatilities in

\footnotetext{
6 The robustness results, reported with U.S. PPI as deflator instead of the CPI, are similar indicating the homogeneity between the PPI-oil and RAC.

7 The annual oil shocks of $\operatorname{pgmax}(12)_{t}$ and $\operatorname{pgmax}(12)_{t}^{01}$ (where the time index $t$ denotes the annual frequency) are the average of 12 monthly oil shocks of $\operatorname{pg\operatorname {max}}(12)_{t}$ and $\operatorname{pg\operatorname {max}}(12)_{t}^{01}$ respectively (where the time index $t$ denotes the monthly frequency). The annual oil price shock/uncertainties are defined as $U(12)_{t}=\operatorname{pg} \max (12)_{t} \times s_{i t}$ and $U(12)^{01}{ }_{t}=\operatorname{pgmax}(12)^{01}{ }_{t} \times s_{i t}$ (where the time index $t$ denotes the annual frequency), the product of annual oil price shocks and annual stock price volatilities. The calculation of monthly oil price shocks and stock volatilities is discussed in Table 1.

${ }^{8}$ We use Baum et al.'s (2008) approach to compute the daily stock volatility that is the square of the daily changes
} 
the accounting year $t$ to capture firm-level uncertainty is attractive since it provides a forward looking indicator of firm's investment opportunity in the next year $t+1 .{ }^{9}$ In addition, the stock volatility is essentially the standard deviation, one scale measure capturing the impact of different potential sources of uncertainty such as taxes and regulations on the firm's value (Bloom et al. (2007) and Baum et al. (2008)).

\subsection{Descriptive statistics and preliminary results}

Table 2 reports the real value of all accounting variables across 20 industries deflated by GDP deflator based on January 1983 dollars. ${ }^{10}$ The investment rates $(I / K)$ are higher for firms in the electrical and electronic machinery industries (e.g., SIC 35, 36, 38). Because of the high-tech downturn over the past decade, these firms have the average loss of stock returns $(R=-2.516)$ and show the highest volatility of stock returns $(s=17.886)$ among all manufacturing companies. The investment rates and stock volatilities are relatively lower for firms in the traditional industries (e.g., SIC 21, 26, 27, 32). Petroleum refining industry has relatively large assets, capital stocks, sales revenues and high stock returns, but relatively low investment rates. It reflects the high profitability of the petroleum industry. Table 3 presents the summary statistics of all variables used over the fiscal years 1962 to 2006. The results show that investment rates increase steadily from 1960 s to 1990 s and decrease substantially from the late 1990 s to 2000 s.

in returns divided by the square root of the number of days intervening. The annual stock price volatility is then defined as the average of past 12 month volatilities where the monthly volatility is the square root of the sum of the daily volatility each month.

9 The reason is that the Compustat accounting data such as investment in the fiscal year $t$ usually end in the first half of the following year $t+1$. A key item in Compustat Xpressfeed is the FYR Year-to-Date Code which designates the month-end for a company's accounting year. Fiscal years ending on January 1 through May 31 are treated as ending in the prior calendar year, whereas a fiscal year beginning on July 1 and ending on June 30 would be reported as the current year. If a fiscal year ends on day 1-14, the Fiscal Year-end Month of data contains a code for the prior month. If a fiscal year ends on or after the 15th, the Fiscal Year-end Month of data contains a code for the current month (see Compustat Online Manual).

10 The literature usually uses the GDP deflator to compute real output to reflect potential changes in consumption patterns over time. We employ the same methodology to present the descriptive statistics of all accounting variables in Tables 2 and 3. We use only ratio variables, the relative values of accounting numbers, in the analysis. The choice of deflator is immaterial. 
The movement of stock returns exhibits a similar pattern over the same period. During the period of falling investment, fluctuations in both stock returns and real oil price growth are pronounced (e.g., the stock volatility (oil price growth) reached the highest at $20.53 \%(7.71 \%$ ) in 2000 (1999)).

In Table 4 we report some results on the link between monthly S\&P 500 index volatilities and oil price shocks. ${ }^{11}$ While firm level uncertainty might be proxied by its stock price uncertainty, uncertainty for the economy as a whole will not be adequately captured solely by volatility in the S\&P 500 index. However, the results Table 4 show that there is a positive association between oil price shocks and aggregate stock price volatility. Table 4 reports the results of four simple regressions in which the dependent variable is the return volatility of the S\&P 500 index and the independent variables are four different oil shocks. $p g_{t}$ denotes the monthly growth rate of real oil price at $t \cdot \operatorname{pgmax}(6)_{t}, \operatorname{pgmax}(12)_{t}$ and $\operatorname{pgmax}(24)_{t}$ denote the monthly growth rates of real oil price at $t$ if the growth rate at $t$ is greater than the maximum of the last 6,12 , and 24 months, respectively, zero otherwise. The first column of Table 4 shows that the growth rate of the real oil price, $p g_{t}$, is highly significant with its t-value almost 9. The result is consistent with Park and Ratti's (2008) finding across European

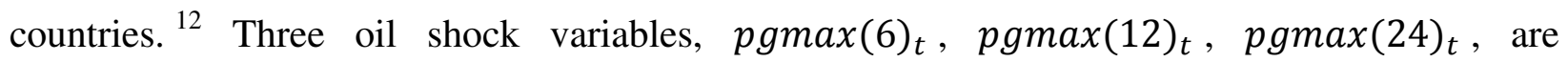
statistically significant at least at the five percent level. ${ }^{13}$

\section{Empirical model and results}

\footnotetext{
11 We also use Baum et al. (2008) approach to compute the monthly S\&P 500 volatility that is the square root of the sum of the daily stock index volatility each month, where the daily volatility is the square of the daily changes in the index returns divided by the square root of the number of days intervening.

12 Park and Ratti (2008) show that oil price shocks account for a statistically significant $6 \%$ of the volatility in stock returns for many European countries.

${ }^{13}$ The level of statistical significance deteriorates as the number of months in defining an oil shock becomes greater. This is because as the number of months increases the number of non-zero oil shocks decreases.
} 


\subsection{The model}

In this section, we describe the investment model to analyze the relationship between firm investment and firm stock price volatility, oil price shocks, and an interaction variable constructed by multiplying oil price shock to the individual firm's stock price volatility. The firm-level investment model has been used by Bloom et al. (2007) and Baum et al. (2008), among others. We will first estimate a model in which oil price shock terms do not appear and then a model in which oil shock terms are introduced. This procedure will allow results to be directly compared to those in the literature on the effect of firm stock price volatility on firm investment and to assess the effect of oil price shocks in the model. The models to be estimated with and without the influence of oil price shocks are given by

$$
\begin{aligned}
\frac{I_{i t}}{K_{i t}}= & \alpha_{1} \frac{I_{i t-1}}{K_{i t-1}}+\alpha_{2} \Delta y_{i t}+\alpha_{3} \frac{c_{i t}}{K_{i t-1}}+\alpha_{4} \frac{c_{i t-1}}{K_{i t-2}}+\alpha_{5}(y-k)_{i t-1}+\alpha_{6}\left(\Delta y_{i t}\right)^{2} \\
& +\alpha_{7} \Delta s_{i t}+\alpha_{8} s_{i t-1}+\alpha_{9} s_{i t} \Delta y_{i t}+A_{i}+\delta_{i}+B_{t}+\xi_{i t} \\
\frac{I_{i t}}{K_{i t}}= & \beta_{1} \frac{I_{i t-1}}{K_{i t-1}}+\beta_{2} \Delta y_{i t}+\beta_{3} \frac{c_{i t}}{K_{i t-1}}+\beta_{4} \frac{c_{i t-1}}{K_{i t-2}}+\beta_{5}(y-k)_{i t-1}+\beta_{6}\left(\Delta y_{i t}\right)^{2} \\
& +\beta_{7} \Delta s_{i t}+\beta_{8} s_{i t-1}+\beta_{9} s_{i t} \Delta y_{i t}+A_{i}+\delta_{i}+B_{t} \\
& +\beta_{10} \Delta o_{t}+\beta_{11} o_{t-1}+\beta_{12} \Delta U_{t}+\beta_{13} U_{t-1}+\beta_{14} o_{t} \Delta y_{i t}+\beta_{15} U_{i t} \Delta y_{i t}+\varepsilon_{i t}
\end{aligned}
$$

where $I_{i t}$ is gross investment of firm $i$ in period $t, K_{i t}$ is the actual capital stock, $C_{i t}$ denotes cash flow, $y_{i t}$ denotes the log of real sales, $k_{i t}$ is the log of capital stock, $(y-k)_{i t-1}$ denotes the error-correction term, $\Delta y_{i t}$ is the first-difference of log of real sales used for the control of firms' demand shocks, $o_{t}$ denotes the real oil price shock in period $t, \Delta o_{t}$ is the first-difference of the oil price shock, $s_{i t}$ denotes the stock price volatility of firm $i$ in period $t, \Delta s_{i t}$ is the firstdifference of the stock price volatility, $U_{i t}$ denotes the oil price shock/stock price volatility faced by firm $i$ at time $\mathrm{t}$ that is defined as the product of oil price shock $o_{t}$ and the firm $i$ 's stock price volatility $s_{i t}$, that is $U_{i t} \equiv o_{t} \times s_{i t}, \Delta U_{i t}$ is the first-difference of $U_{i t}, A_{i}$ and $B_{t}$ are 
unobserved firm-specific and time-specific effects, $\delta_{i}$ is the firm-specific depreciation rate, and $\varepsilon_{i t}$ is the serially uncorrelated error term.

The equation (6) with the exception of the lagged dependent variable is the equation estimated with U.K. company data by Bloom et al. (2007). Equation (7) incorporates multiple influences of oil price shocks on firm investment. Direct effects are captured by the firstdifference and the lag of real oil price shock variables, $\Delta o_{t}$ and $o_{t-1}$. Interaction effects of oil price shock and firm stock price volatility on firm investment are captured in the variables $\Delta U_{t}$ and $U_{t-1}$, with firm sales growth is captured in the term $o_{t} \Delta y_{i t}$, and also in further interaction with both firm stock price volatility and firm sales growth in the term $U_{i t} \Delta y_{i t}$.

Note that the dependent variable, investment-capital ratio, is stationary and all righthand-side variables are also stationary given the cointegrating relationship between the log of real sales $y_{i t}$ and the log of capital stock $k_{i t}{ }^{14}$ The growth rate of real sales $\Delta y_{i t}$ is to capture the effect of sales growth on the investment-capital stock ratio. The square of the growth rate of real sales $\left(\Delta y_{i t}\right)^{2}$ is to reflect a potential non-linear effect of sales growth on investment. The cointegrating term $(y-k)_{i t-1}$ is to incorporate the long-run effect of the log of real salescapital ratio on investment. The change (lag) of oil price shock/uncertainty $\Delta U_{i t}\left(U_{i t-1}\right)$ is to capture the short-run (long-run) effect of firm-level uncertainty on investment. ${ }^{15}$

The OLS estimation results of equation (7) are reported in Table $5 .{ }^{16}$ Column (1) contains the standard OLS estimates without the firm specific effect and the time effect. The coefficients of the change in oil shock, the lagged oil shock, the change in stock volatility, and

\footnotetext{
${ }^{14}$ Assuming a constant-returns-to-scale technology, $\log \left(\frac{\mathrm{Q}}{\mathrm{L}}\right)=\log (\mathrm{A})+\alpha \log \left(\frac{\mathrm{K}}{\mathrm{L}}\right)$, where $\mathrm{Q}, \mathrm{L}, \mathrm{K}$, and A denotes, respectively, output, labor, capital, and technology, it is clear that $\log \left(\frac{\mathrm{Q}}{\mathrm{L}}\right)$ and $\log \left(\frac{\mathrm{K}}{\mathrm{L}}\right)$ are cointegrated as long as $\log (\mathrm{A})$ is an $\mathrm{I}(0)$ process which is very likely. Thus, the $\log$ of real sales $y_{i t}$ and $\log$ of capital stock $k_{i t}$ should be cointegrated.

${ }_{15}$ The 'long-run' in this paper represents a year or longer time span.

${ }^{16}$ Note that the OLS estimators may not be consistent because of the potential generated regressor problem.
} 
the lagged stock volatility are all positive and statistically significant. The positive coefficients of oil shock variables and stock volatility variables are counter-intuitive. Column (2) shows the results when the firm specific effect is included in the model. The coefficient of the change in oil shock is significant at the five percent level and the lagged oil shock are now insignificant, suggesting that oil shock has only a short-term effect on the firm-level investment. Column (3) contains the results when both the firm-specific and time-specific effects are included in the model. ${ }^{17}$ The coefficient estimates of the change in oil shocks and lagged oil shocks are insignificant at the five percent level, whereas the change in stock volatility, lagged stock volatility, change in uncertainty, and lagged uncertainty are all negative and significant at least at the five percent level. Note that the least-squares estimates do not take into account the possibility of unmeasured errors or endogenous explanatory variables. In order to avoid this potential weakness, GMM is used to estimate the model parameters. ${ }^{18}$

\subsection{The effects of oil price shocks on firm-level investment}

The system GMM estimator is developed by Arellano and Bover (1995) and Blundell and Bond (1998). It combines a system of equations in first differences using lagged levels of endogenous variables as instruments with equations in levels for which lagged differences of endogenous variables are used as instruments. Following Bloom et al. (2007), such variables as sales, cash flows, oil shocks, and stock volatilities are considered as endogenous. To allow for potentially long delays in oil shock transmission, a set of instruments with a lag length up to 15 is used in the first-difference equations. ${ }^{19}$ The Instrument validity is tested using a Sargan-

\footnotetext{
17 The standard errors in both columns (2) and (3) are robust to heteroscedasticity.

18 The system GMM estimation module in STATA 11 is used for the estimation.

${ }^{19}$ When the instruments were set as the second through fifteenth lags of exogenous variables, the system GMM estimation module in STATA 11 automatically drops firms that have observations less than 15. This leaves about 60,000 firm-year observations of 3,000 firms. A panel model with large cross-sections and time-series requires a relatively large number of over-identifying restrictions to have GMM estimates consistent (Davidson and
} 
Hansen test of over-identifying restrictions.

Table 6 reports the results of GMM estimation. ${ }^{20}$ The dependent and independent variables are the same as those in Bloom et al. (2007) except for the oil shock variable, and variables in interaction with the oil shock variable ${ }^{21}$ In Bloom et al. (2007), the within-year standard deviation of daily returns is used, whereas the average on 12-month standard deviations of daily returns is used for firm $i$ in accounting year $t$, denoted $s_{i t}$, in this paper. Regardless of the variable chosen for the uncertainty measure, the lagged investment rate $I_{i t-1} / K_{i t-2}$, sales growth $\Delta y_{i t}$, lagged cash flow $C_{i t-1} / K_{i t-2}$, error correction term $(y-k)_{i t-1}$, and sales growth squared $\left(\Delta y_{i t}\right)^{2}$ all have intuitive signs and are highly significant with the minimum t-value 2.71. For all six models, the Lagrange multiplier tests for the presence of the second-order serial correlation in the error term cannot reject the null hypothesis of no serial correlation. For all six models, Sargan-Hansen tests do not reject the validity of the over-identifying restrictions. The goodness-of-fit statistics measured by the squared correlation coefficient between actual and predicted levels of the dependent variable suggest that all six models have pretty good explanatory power.

\subsubsection{Benchmark result without oil price shocks}

Column (1) of Table 6 contains the estimation results of equation (6) (for U.S. manufacturing firms) and may be compared to Bloom et al.'s (2007) results (in their Table 5) for

\footnotetext{
MacKinnon, 1993).

${ }^{20}$ The individual firm's stock returns volatility $s_{i t}$ is generated using firm's past stock returns that may induce a potential generated regressor problem. If, however, future investment plans are announced not more than a year ahead, the stock return volatility and the uncertainty variables used in the text will not be correlated with the dependent variable, $\frac{I_{i t}}{K_{i t}}$. When the future investment plan is announced, stock price will reflect the plan immediately, creating a correlation between past stock returns and current investment. However, if all investment plans are announced less than a year ahead, that, we believe, is the common practice, then past stock return volatilities $S_{i t-i}$, $i=1,2, \ldots$ will not be correlated with current investment. Since $s_{i t-i}, i=1,2, \ldots$ are used as instruments in GMM estimation and the frequency of data is annual, the GMM estimates will not suffer from the generated regressor problem and hence the estimators in Table (6) are consistent and their standard errors are not biased.

${ }^{21}$ Note that the lagged investment rate is not used in Bloom et al. (2007).
} 
U.K. manufacturing company data between 1972 and 1991 and may serve as a bench mark for evaluating the role of oil price shocks in the model. The results are very similar for the U.K. and U.S. firm data. In both sets of results sales growth, the cash flow variables, sales growth squared and the error correction term have positive statistically significant coefficients. The statistical significance of both the level and the square of sales growth is consistent with the prediction from the partial irreversibility of investment model in Bloom et al. (2007) of a convex relationship between investment and demand shocks. In Bloom et al. (2007), the linear stock price volatility terms, $\Delta s_{i t}$ and $s_{i t-1}$, are negative and either statistically insignificant or only marginally significant. In column (1) of Table 6 the coefficient estimate of the lag of stock price volatility $s_{i t-1}$ is negative and highly significant indicating that firm-specific uncertainty has a long-term impact on investment spending. The coefficient estimate of the change in stock price volatility $\Delta s_{i t}$ is positive and significant at the ten percent level. ${ }^{22}$ Baum et al. (2008) interpret the positive coefficient on the firm specific uncertainty as the existence of a real option value for firm managers regarding investment decisions. In other words, the managers would buy or sell their stock options to facilitate their firms to possess a greater opportunity to expand firms' presence in the market. A joint Wald test for the exclusion of the change in firm-level stock price volatility $\Delta s_{i t}$ and the lag of firm-level stock price volatility $s_{i t-1}$ rejects the null. The finding indicates that such real option value may exist. The coefficient estimate of the interaction term $\Delta s_{i t} * \Delta y_{i t}$ is negative and significant with an absolute t-value 2.63.

The finding that an increase in firm-level uncertainty measured by firm stock price volatility reduces the link between sales growth and investment replicates with U.S. firm data the

${ }^{22}$ Our finding is different from that of Bloom et al. (2007) in which the coefficient of the change in stock price volatility is negative but insignificant. The difference may be due to a number of reasons: the difference in the construction of stock price volatility, the addition of the lag of investment rate as a regressor, different sample periods and the U.S. vs. U.K. data. 
finding by Bloom et al. (2007) for U.K. firm data. Bloom et al. (2007) regard this as "the main result of interest" (p. 408) since it suggests that higher uncertainty reduces the effect of a rise in sales growth (induced by stimulating demand) on firm investment. Firms become more cautious when uncertainty is higher.

\subsubsection{Direct effect of oil price shocks}

Columns (2) and (3) of Table (6) report results when the model includes the oil shock variables, $\Delta o_{t}$ and $o_{t-1}$ where $o_{t}=\operatorname{pgmax}(12)_{t}$ and $\operatorname{pgmax}(12)_{t}$ is equal to the growth rate of real oil price $p g_{t}$ if $p g_{t}$ is greater than the maximum of the last 12 months and zero otherwise. In both regressions the effects of the oil shock variables are measured by the change in oil price shock and the lag of oil price shock. Firm stock price volatility is excluded in column (2) but included in column (3). The main objective of column (3) is to compare the results when two oil shock variables are added to Bloom et al.'s (2007) investment model, equation (6). In both columns (2) and (3) the coefficient estimate of the lag of oil shock, $o_{t-1}$, is statistically significant. ${ }^{23}$ The result is consistent with the findings of Elder and Serletis (2010) and Rahman and Serletis (2010), among others, in that oil price shocks affect long-run firm-level capital accumulation. Note that an interaction term between oil price shock and sales growth $o_{t} * \Delta y_{i t}$ is included in both columns (2) and (3). This term has a negative coefficient and is statistically significant in column (2) but not in column (3). The results, not shown, suggest that the exclusion of the interaction term do not alter the significance of other coefficient estimates in columns (2) and (3).

The change in oil price shock, $\Delta o_{t}=\Delta \operatorname{pg} \max (12)_{t}$, is not statistical significant in column (2) but is significant in column (3), indicating that the statistical significance of the short-

${ }^{23}$ Three other oil price shocks, $p g_{t}, \operatorname{pgmax}(6)_{t}, \operatorname{pgmax}(24)_{t}$, are also tried with similar results. 
run effects of oil price shock on firm investment is sensitive to the presence of other explanatory variables, in particular the firm stock price volatility. The results in column (3) indicate that oil price shocks have statistically significant negative effects on firm-level investment spending both in the short and long-run. Note, however, that the statistical significance of oil shock variables disappears when oil price shock/uncertainty variables are included in the model as can be seen from column (6).

\subsubsection{The effects of oil price shock/uncertainty on firm-level investment}

The effects of oil price shock/uncertainty (stock price volatility) on firm investment are investigated in this section. Columns (4)-(6) of Table 6 show the results when the change and the lag of oil price shock/uncertainty, $\Delta U_{i t}$ and $U_{i t-1}$, are included in the regression equations. In column (4), both oil shock variables and firm stock price volatility variables are excluded while in column (5) oil shock variables are excluded. Column (6) contains all variables in equation (7).

In columns (4)-(6) both the change in the oil price shock/uncertainty $\Delta U_{i t}$ and the lag of oil price shock/uncertainty $U_{i t-1}$ have negative effects on investment, and their coefficient estimates are statistically significant at the one percent level, except for the coefficient estimate of the change in oil price shock/uncertainty in column (4). The statistical significance of both $\Delta U_{i t}$ and $U_{i t-1}$ indicates that the oil price shock/uncertainty has both short and long-run effects on the firm investment decision. Column (6) shows the results when all variables of equation (7) are included in the regression. Two notable findings should be mentioned. First, oil price shock variables become insignificant. A comparison of the results in columns (3) and (6) suggests that the explanatory power of oil shock variables is absorbed by oil shock/uncertainty variables. ${ }^{24}$ Secondly, the change in stock price volatility $\Delta s_{i t}$ is positive and significant but the lag of stock

\footnotetext{
${ }^{24}$ The addition of the uncertainty*sales growth variable in column (3) does not alter the significance of oil shock variables.
} 
price volatility $s_{i t-1}$ is not, suggesting that stock price volatility has only short-run positive effects on investment in the presence of oil shock/uncertainty variables.

The results in columns (3)-(6) indicate that the lag of oil price shock/uncertainty has strong and consistent negative effects on firm investment and its statistical significance is not very sensitive to the presence of either oil shock variables or stock price volatility variables. Thus, oil price shock/uncertainty has significant long-run negative effects on capital accumulation of individual firms. In contrast, the statistical significance of the short-run effects of oil shock/uncertainty turns out to be sensitive to the presence of oil shock variables and stock price volatility variables. It seems that its statistical significance is bolstered (depressed) by the presence of stock price volatility variables (oil price shock variables). The interaction term between oil price shock/uncertainty and sales growth $U_{i t} * \Delta y_{i t}$ is not significant in columns (5) and (6). However, the statistical significance of the link between sales growth and investment drops when oil shock variables are included in the model (see columns (3) and (6) of Table 6).

The results overall in Table 6 suggest that oil price shocks have a larger effect reducing investment at firms with greater stock price volatility, or as Bloom et al. (2007) argue at firms with greater uncertainty. Table 6 provides evidence that firm investment is affected not directly by linear terms in change in or lag in real oil price shocks, but by the interaction between oil price shocks and an individual firm's uncertainty (stock price volatility). This result is in line with the theory of real options in capital budgeting decisions, that predicts that uncertainty about, for example, output prices, will cause firms to delay production and investment. The stock price volatility of an individual firm represents uncertainty associated with the firm's activity and a firm facing higher uncertainty is more vulnerable to a negative oil price shock. It is interesting that Elder and Serletis (2010) find that the presence of oil price volatility amplifies the negative 
effects of oil price shocks on industrial production. At firm level we find that the negative effect of an oil price shock is greater at firms facing greater uncertainty.

\subsubsection{Is the magnitude of the oil price shock important?}

We now turn to the issue of whether the size of the oil price shock is important or is it just the real oil price itself, once recognized as such, that affects real economic activity. This question is of particular interest in the current context, since the effect of oil price shock on investment is associated with the variable, $U(12)_{i t}$, the product of the magnitude of oil price shock and firm stock price volatility.

In column (1) of Table 7 change in and the lag of the oil shock (dummy) variable $\operatorname{pgmax}(12)_{t}^{01}$ (equal to 1 if $\operatorname{pgmax}(12)_{t}$ is positive and 0 otherwise) are introduced into the benchmark regression equation, and in columns (2) and (3) of Table 7 change in and the lag of the oil shock in interaction with firm stock price volatility variable $U(12)_{i t}^{01}=$ $\operatorname{pgmax}(12)_{t}^{01} \times s_{i t}$ are introduced into the benchmark regression equation. ${ }^{25}$ In column (4) of Table 7 change in and the lag of both $\operatorname{pgmax}(12)_{t}^{01}$ and $U(12)_{i t}^{01}$, variables independent of the size of oil price shock, appear in the regression equation. The pattern of results in columns (1) through (4) of Table 7 is very similar to the equivalent results in Table 6 for $\operatorname{pgmax}(12)_{t}$ and for $U(12)_{i t}$. The direct effect of the dummy indicator variable for the oil price shock is statistically significant in column (1) and the dummy indicator variable for oil price shock in interaction with firm stock price volatility is statistically significant in columns (2) and (3). However, in column (4) the variables $\Delta \operatorname{pgmax}(12)_{t}^{01}$ and $\operatorname{pgmax}(12)_{t-1}^{01}$ are not

\footnotetext{
${ }^{25}$ Rahman and Serletis (2010) investigate the differential effects of oil price shocks with varying sign-size combinations. Here, the oil price shock is either positive or zero and the issue is whether the size of the positive shock is important. The result in this paper is consistent with their finding that there is no positive size bias (see their Panel D of Table 1).
} 
statistically significant, whereas the variables $\Delta U(12)_{i t}^{01}$ and $U(12)_{i t-1}^{01}$ are statistically significant, indicating that the dummy variable indicating an oil price shock in interaction with firm stock price volatility has a negative effect on firm investment and is the dominant path way by which an oil shock influences firm investment. This is consistent with the result in the previous subsection that an oil price shock in interaction with firm stock price volatility has a negative significant effect on firm investment whereas linear terms in change in and lag of oil price shock is not significant.

To determine whether the magnitude of the oil price shock is important in influencing firm investment we introduce the change in and the lag of $U(12)_{i t}^{01}$ and $U(12)_{i t}$ into the bench mark model. This result is reported in column (5) of Table 7. In column (5) $\Delta U(12)_{i t}$ is not statistically significant but the variables $U(12)_{i t-1}, \Delta U(12)_{i t}^{01}$ and $U(12)_{i t-1}^{01}$ are statistically significant and all have negative coefficients. The results imply that for the short-term effects of the oil price shock/uncertainty variable the particular magnitude of an oil price shock is not important in interaction with stock price volatility in determining investment. What is important is that there is an oil price shock, that is $\Delta U(12)_{i t}$ is not significant but $\Delta U(12)_{i t}^{01}$ is. For the long-term effects, however, the magnitude of the oil price shock does matter, i.e., $U(12)_{i t-1}$ is significant. The bigger the oil shock $\operatorname{pg} \max (12)_{t}$ is, the greater the decline in investment over a longer horizon. The null hypothesis that the variables $\Delta U(12)_{i t}^{01}$ and $U(12)_{i t-1}^{01}$ have equal coefficients cannot be rejected at the $1 \%$ level of confidence. ${ }^{26}$ These latter variables may be combined as $U(12)_{i t}^{01}$. In column (6) of Table 7 we look at the effect of introducing $U(12)_{i t}^{01}$, $\Delta U(12)_{i t}$ and $U(12)_{i t-1}$ into the bench mark model. We find that the coefficients of both

\footnotetext{
${ }^{26}$ The joint Wald test of the null hypothesis that the coefficients on the variables $\Delta U(12)_{i t}^{01}$ and $U(12)_{i t-1}^{01}$ are both zero has a $\chi^{2}(2)$ statistic of 9.83 with a p-value of 0.007 , and the joint Wald test of the null hypothesis that the coefficients on both variables $\Delta U(12)_{i t}^{01}$ and $U(12)_{i t-1}^{01}$ are equal has a $\chi^{2}(1)$ statistic less than 0.001 with a pvalue of 0.991 . Thus, the variables are combined as $U(12)_{i t}^{01}$.
} 
$U(12)_{i t}^{01}$ and $U(12)_{i t-1}$ are negative and statistically significant.

\subsubsection{The interaction with sales growth}

Bloom et al. (2007) suggest that an increase in a firm's stock volatility reduces the link between sales growth and investment. If the firm is facing greater uncertainty, stimulating demand and raising sales growth will only provide relatively small increases in investment. In columns (5) and (6) of Table 6 and columns (5) and (6) of Table 7 the interaction term $\Delta s_{i t} \times \Delta y_{i t}$ is negative and statistically significant, but interaction terms of oil price shocks with $\Delta s_{i t} \times \Delta y_{i t}$ are not statistically significant. The finding in these columns is that an oil price shock in interaction with firm stock price volatility is statistically significant, but interaction of an oil price shock/uncertainty with sales growth $U_{i t} \times \Delta y_{i t}$ is not statistically significant. One

other aspect worth mentioning with regard to the effect of oil price shocks on the relationship between sales growth and investment is that most significant oil price shocks are supply driven and hence firm investment may react differently than to demand driven shocks.

Table 8 reports results for a parsimonious model in which only an oil price shock in interaction with firm stock price volatility and sales growth is added to the bench mark model in equation (6). While column (1) of Table 8 shows that the coefficient estimate of the interaction term $U_{i t} \times \Delta y_{i t}$ is negative and marginally significant at the ten percent level, column (2) reports that the coefficient estimate of the interaction term is negative but insignificant. These results reinforce the finding that oil price shocks work through the interaction with firm stock price volatility alone.

\subsubsection{Real oil price shocks calculated by PPI}

In Table 9 we report results from estimating equation (7) when oil price shocks are constructed on the basis of nominal oil price deflated by the U.S. PPI rather than the U.S CPI. In 
columns (1) and (2) of Table 9, estimation results for the growth rate of real oil price, with nominal oil price obtained by deflating with the CPI and the PPI appear, respectively. The results are very similar in columns (1) and (2), and show that linear terms in the growth rate in real oil price are not statistically significant and that there is a marginal negative impact from a lag in a rise in the growth rate of real oil price in interaction with firm daily stock price. In columns (3) and (4) results from estimating equation (7) when the real oil price shocks are given by $\operatorname{pgmax}(12)_{t}$ and $\operatorname{pgmax}(12)_{t-1}^{01}$ constructed on the basis of nominal oil price being deflated by the PPI, respectively. The results in columns (3) and (4) in Table 9 for the PPI deflator are directly comparable to the results using the CPI as deflator in column (6) of Table 6 and column (4) of Table 7, respectively. In columns (3) and (4) in Table 9 linear terms in the change in and lag of real oil price shock are not statistically significant and the negative effects on investment from interaction of real oil price shock with firm stock price volatility, $\Delta U_{i t}$ and $U_{i t-1}$, are highly statistically significant.

The robustness tests guard against our results that oil price shocks influence firm investment and that the interaction with firm stock price volatility is dominant in effect. The negative effect of an oil price shock on a firm's investment is larger in absolute value the larger is a firm's stock price volatility. In the presence of interaction terms between oil price shocks and firm stock price volatility, an oil price shock on its own is not statistically significant. As the magnitude of the oil price shock/uncertainty is independent of the size of oil price shock, the estimation results are more pronounced suggesting that the identification of a shock is very important. The particular magnitude of that oil price shock given that it is a shock is less important. Thus, the effect of an oil price shock on a firm's investment depends on it being a shock and on the level of the firm's stock price volatility. 


\section{Conclusion}

This paper examines the effect of real oil price shocks on firm level investment, both directly and in interaction with firm stock price volatility and with firm sales growth. With data on over 3,000 U.S. manufacturing firms for 1962-2006 a dynamic firm-level investment equation is estimated. The results suggest that oil price shocks influence firm investment in interaction with firm stock price volatility. Bloom et al. (2007) have identified firm stock price volatility as a surrogate for uncertainty faced by the firm. The results in this paper therefore suggest that oil price shocks depress investment more at firms facing greater uncertainty (indicated by firm stock price volatility) than at firm facing less uncertainty.

In the presence of interaction terms between change and lag in real oil price shocks and firm stock price volatility, linear terms in change and lag in real oil price shocks are not statistically significant. The interaction of oil price shocks with firm level uncertainty is the dominant channel by which oil price shocks affect firm investment. The negative effect of an oil price shock on a firm's investment is larger in absolute value the larger is a firm's stock price volatility, both in the short and in the long-term.

The results imply that for the short-term effects of the oil shock/uncertainty variable, the particular magnitude of oil shock may not be as important as the fact that there is an oil shock. For the long-term effects, however, the magnitude of oil price shock does matter. Over a longer horizon, oil price shocks depress investment more at firms facing greater uncertainty that is measured by stock price volatility. An increase in firm stock price volatility continues to reduce the link between sales growth and investment in the presence of oil price shocks as in Bloom et al. (2007). 


\section{References}

Aloui, M. and R. Jammazi (2009), "The effects of crude oil shocks on stock market shifts behavior: A regime switching approach," Energy Economics, 31, 789-799.

Arellano, M. and S. Bond (1991), "Some Tests of Specification for Panel Data: Monte Carlo Evidence and an Application to Employment Equations," Review of Economic Studies, 58, 277-97.

Arellano, M. and O. Bover (1995), "Another Look at the Instrumental-Variable Estimation of Error Components Models," Journal of Econometrics, 68, 29-52.

Barsky, R.B. and L. Kilian (2002), "Do we really know that oil caused the Great Stagflation? A monetary alternative," in NBER Macroeconomics Annual 2001, 16, 137-183.

(2004), "Oil and the Macroeconomy since the 1970s," Journal of Economic Perspectives, American Economic Association, 18, 115-134.

Baum, C., M. Caglaynan, and O. Talavera (2008), "Uncertainty Determinants of Firm Investment," Economics Letters, 98, 282-287.

Bernanke, B. (1983), "Irreversibility, Uncertainty, and Cyclical Investment," Quarterly Journal of Economics, 98, 85-106.

Bloom, N. (2007), “The Impact of Uncertainty Shocks,” NBER Working Paper 13385.

Bloom, N., S. Bond, and J. Van Reenen (2007), "Uncertainty and Investment Dynamics," Review of Economic Studies, 74, 391-415.

Blundell, R. and S. Bond (1998), "Initial Conditions and Moment Restrictions in Dynamic Panel Data Models," Journal of Econometrics, 87, 115-143.

Chen, N. R. Roll, and S.A. Ross (1986), "Economic Forces and the Stock Market," The Journal of Business, 59, 3, 383-403.

Davidson, R. and J.G. MacKinnon (1993), Estimation and Inference in Econometrics, Oxford University Press, New York, NY.

Driesprong, G., B. Jacobsen, and B. Maat (2008), “Striking Oil: Another Puzzle?” Journal of Financial Economics, 89, 307-327.

Edelstein, P. and L. Kilian (2007a), "Retail Energy Prices and Consumer Expenditures," mimeo, Department of Economics, University of Michigan. (2007b), “The Response of Business Fixed Investment to Changes in Energy Prices: A 
Test of Some Hypothesis about the Transmission of Energy Price Shocks," The B.E. Journal of Macroeconomics, Contributions, 7, Article 35.

Elder, J. and A. Serletis (2010), “Oil Price Uncertainty," Journal of Money, Credit, and Banking, forthcoming.

Engemann, K.M., K.L. Kliesen, and M.T. Owyang (2010), "Do Oil Shocks Drive Business Cycles? Some U.S. and International Evidence," Federal Reserve Bank of St. Louis Working Paper 2010-007A.

Fukunaga, I., N. Hirakata, and N. Sudo (2010), "The Effects of Oil Price Changes on the Industry-Level Production and Prices in the U.S. and Japan,” NBER Working Paper 15791.

Gilchrist, S. and C. Himmelberg (1999), "Investment: Fundamentals and Finance," in NBER Macroeconomics Annual 1998, 13, 223-274.

Gogineni, S. (2009), "Oil and the Stock Market: An Industry Level Analysis," Working Paper, University of Oklahoma.

Hamilton, J.D. (1988), “A Neoclassical Model of Unemployment and the Business Cycle," Journal of Political Economy, 96, 593-617.

(1996), "This is What Happened to the Oil Price-Macroeconomy Relationship," Journal of Monetary Economics, 38, 215-220. (2005), "What's Real About The Business Cycle?" Federal Reserve Bank of St. Louis Review, 87, 435-452. (2008), "Oil and the Macroeconomy," in Durlauf, S.N. and Blume, L.E. (eds.) The New Palgrave Dictionary of Economics, Second Edition, Houndmills, U.K., Palgrave Macmillan. Hooker, M.A. (1996), "What Happened to the Oil Price-Macroeconomy Relationship," Journal of Monetary Economics, 38, 195-213.

Huang, R.D., R.W. Masulis, and H.R. Stoll (1996), "Energy Shocks and Financial Markets," Journal of Futures Markets, 16, 1-27.

Jones, C.M. and G. Kaul (1996), "Oil and the Stock Markets," Journal of Finance, 41, 2, 463491.

Kilian, L. (2007), "The Economic Effects of Energy Price Shocks," CEPR Discussion Papers 6559, C.E.P.R., discussion Papers. (2008a), "Exogenous Oil Supply Shocks: How Big Are They and How Much Do They Matter for the U.S. Economy," Review of Economics and Statistics, 90, 216-240. 
(2008b), "The Economic Effects of Energy Price Shocks," Journal of Economic Literature, 46(4), 871-909.

(2009a), "Not All Oil Price Shocks Are Alike: Disentangling Demand and Supply Shocks in the Crude Oil Market," American Economic Review, 99, 1053-1069. (2009b) , "Oil Price Volatility: Origins and Effects," World Trade Organization Staff Working Paper ERSD-2010-02.

Kilian, L. and C. Park (2009), "The Impact of Oil Price Shocks on the U.S. Stock Market," International Economic Review, 50, 1267-1287.

Leahy, J.V. and T.M. Whited (1996), "The Effect of Uncertainty on Investment: Some Stylized Facts," Journal of Money, Credit and Banking, 28, 64-83.

Lee, K. and S. Ni (2002), "On the Dynamic Effects of Oil Price Shocks: A Study Using Industry Level Data," Journal of Monetary Economics, 49, 823-852.

Lee, K., S. Ni, and R.A. Ratti (1995), "Oil Shocks and the Marcoeconomy: The Role of Price Variability," Energy Journal, 16, 39-56.

Love, I. (2003), "Financial Development and Financing Constraints: International Evidence from the Structural Investment Model,” The Review of Financial Studies, 16, 765-791.

Merton, R.C. (1980), "On estimating the expected return on the market: an exploratory investigation," Journal of Financial Economics, 8, 323-361.

Mork, K.A. (1989), "Oil and the Macroeconomy. When Prices Go Up and Down: An Extension of Hamilton's Results," Journal of Political Economy, 97, 740-744.

Park, J.W. and R.A. Ratti (2008), "Oil price shocks and stock markets in the U.S. and 13 European countries," Energy Economics, 30, 2578-2608.

Pollet, J. (2004), "Predicting Asset Returns with Expected Oil Price Changes," Working Paper, Goizueta Business School, Emory University, 1-31.

Pindyck, R.S. (1991), "Irreversibility, Uncertainty, and Investment," Journal of Economic Literature, 29, 1110-1148

Rahman, S. and A. Serletis (2010), "The Asymmetric Effects of Oil Price Shocks," Macroeconomic Dynamics, forthcoming.

Sadorsky, P. (1999), "Oil price shocks and stock market activity," Energy Economics, 2, 449-469.

Windmeijer, F. (1995), "A Note on $\mathrm{R}^{2}$ in the Instrumental Variables Model," Journal of Quantitative Economics, 11, 257-261. 
Table 1. Variable definitions

\begin{tabular}{|c|c|c|}
\hline Variable & Acronym & Definition \\
\hline \multicolumn{3}{|c|}{ From COMPUSTAT (Fiscal year $1962-2006, M M \$=$ million U.S. dollars) } \\
\hline Total assets & TA & Total assets at the beginning of the period $\mathrm{t}(\mathrm{MM} \$)$ \\
\hline Capital stock & $\mathrm{K}$ & Net property, plant and equipment (MM\$) \\
\hline Sales (net) & S & $\begin{array}{l}\text { Total current operating revenue plus net pretax profit or loss on securities sold or redeemed minus } \\
\text { non- recurring income at the end of period }(\mathrm{MM} \$ \text { ) }\end{array}$ \\
\hline Investment & IK & Net capital expenditure scaled by capital(t-1) \\
\hline Net sales & SK & Sales (net) at the end of period t scaled by capital \\
\hline Cash flow & CFK & $\begin{array}{l}\text { Income before extraordinary items plus depreciation and amortization } \\
\text { scaled by capital (MM\$) }\end{array}$ \\
\hline Tobin's $Q^{a}$ & TQ & $\begin{array}{l}\text { Market value plus book value of assets minus common equity and deferred taxes scaled by the book } \\
\text { value of assets }\end{array}$ \\
\hline \multicolumn{3}{|c|}{ From CRSP (January 1, 1962 - December 31, 2007) } \\
\hline Return (daily) & $\mathrm{R}$ & Daily stock price returns including dividends \\
\hline Return (annual) & $\mathrm{R}$ & $\begin{array}{l}\text { Annual stock price returns, the average of } 12 \text {-month returns where the monthly stock return is the } \\
\text { accumulative daily stock returns }\end{array}$ \\
\hline Volatility & $s_{i t}$ & $\begin{array}{l}\text { Annual stock volatility, the average of } 12 \text {-month standard deviations of daily returns for firm i in accounting } \\
\text { year } t \text { where the monthly standard deviation is computed using Baum et al.' (2008) approach }\end{array}$ \\
\hline \multicolumn{3}{|c|}{ From U.S. Department of Energy (January 1974 - December 2007, extended back to January 1962, deflated by CPI, and based on January 1983 dollars) } \\
\hline Oil price growth rate $p g_{t}$ & $\begin{array}{l}\text { Annual gre } \\
\text { difference }\end{array}$ & $\begin{array}{l}\text { f oil prices, the average of } 12 \text { monthly growth rates where the monthly growth rate is the first } \\
\text { logarithm of the monthly refiner acquisition cost (RAC) of imported crude oil }\end{array}$ \\
\hline Oil price shock $\quad \operatorname{pgmax}(12)_{t}$ & $\begin{array}{l}\text { Annual oil } \\
\operatorname{pgmax}(12\end{array}$ & $\begin{array}{l}\text { cks } \operatorname{pgmax}(12)_{t} \text { (where the time index } t \text { denotes annual frequency), is the average of } 12 \text { monthly oil price shocks } \\
\text { he time index } t \text { denotes monthly frequency). The monthly oil price shock is set equal to the growth rate of real }\end{array}$ \\
\hline
\end{tabular}

oil price at time $t, p g_{t}$, if $p g_{t}$ is greater than the maximum growth rate of the last 12 months and zero otherwise.

\begin{abstract}
Notes: The sample is an unbalanced panel on individual manufacturing firms (with SIC 2000-3999) between 1962 and 2007. ${ }^{\text {a }}$ Tobin's $Q$ is essentially a firm's market-to-book ratio. Higher values of Tobin's q reflect investors' optimistic about firms' future asset returns. ${ }^{b}$ PRCCI (Compustat data item 199) is the close price of equity and SHOI (Compustat data item 25 ) is the shares outstanding. General rules with regard to the data are the following. Firm-level data is eliminated if a firm has three or less years of coverage, if there are missing values for investment, capital stock, sales, and cash flow, and if there are observations with negative values for assets, sales, or capital stock. In addition, we follow Gilchrist and Himmelberg (1998) and Love (2003) to exclude observations with $I K>2.5$, $S K>20$, and outliers in the top and bottom 5\% of the accounting data from COMPUSTAT database. We also eliminate firms with missing or inconsistent data and exclude firms with less than 12 months of past return data from CRSP database. Stocks in the top and bottom $1 \%$ of the variable values are also excluded. The final data set contains 69113 firm-years pertaining to 3322 firms with complete data for all variables used in the analysis
\end{abstract}


Table 2. Descriptive statistics across industries

\begin{tabular}{|c|c|c|c|c|c|c|c|c|c|c|c|c|c|}
\hline Industry & SIC & Industry name & TA & K & S & CFK & IK & SK & TQ & $\mathrm{R}$ & s & $\begin{array}{c}\text { Number of } \\
\text { observations }\end{array}$ & $\begin{array}{c}\text { Percent of } \\
\text { observations }\end{array}$ \\
\hline 1 & 20 & Food and kindred products & 15.570 & 5.821 & 22.983 & 0.240 & 0.254 & 5.095 & 1.496 & 8.297 & 13.203 & 4661 & 7.888 \\
\hline 2 & 21 & Tobacco manufactures & 37.524 & 9.494 & 40.672 & 0.463 & 0.228 & 5.734 & 1.823 & 7.110 & 9.489 & 216 & 0.366 \\
\hline 3 & 22 & Textile mill products & 5.221 & 1.841 & 7.057 & 0.224 & 0.249 & 4.915 & 1.051 & 0.801 & 14.517 & 1675 & 2.835 \\
\hline 4 & 23 & Apparel and fabrics-based products & 5.532 & 1.111 & 6.603 & 0.363 & 0.275 & 9.060 & 1.314 & 3.765 & 13.884 & 1665 & 2.818 \\
\hline 5 & 24 & Lumber and wood products & 8.384 & 4.032 & 8.006 & 0.230 & 0.260 & 5.780 & 1.327 & -0.886 & 14.867 & 1141 & 1.931 \\
\hline 6 & 25 & Furniture and fixtures & 5.437 & 1.487 & 8.115 & 0.316 & 0.255 & 6.102 & 1.292 & 3.137 & 13.473 & 1312 & 2.220 \\
\hline 7 & 26 & Paper and allied products & 20.826 & 11.806 & 19.725 & 0.224 & 0.228 & 3.084 & 1.294 & 3.157 & 12.068 & 2459 & 4.161 \\
\hline 8 & 27 & Printing and publishing & 9.373 & 2.504 & 8.629 & 0.335 & 0.272 & 5.268 & 1.597 & 6.086 & 12.382 & 2583 & 4.371 \\
\hline 9 & 28 & Chemicals and allied products & 15.458 & 5.994 & 15.431 & -0.025 & 0.266 & 4.302 & 2.239 & 0.961 & 14.614 & 7516 & 12.719 \\
\hline 10 & 29 & Petroleum refining & 34.426 & 20.669 & 38.170 & 0.181 & 0.230 & 2.815 & 1.248 & 12.203 & 13.179 & 1024 & 1.733 \\
\hline 11 & 30 & Rubber and plastics products & 6.616 & 2.376 & 8.190 & 0.227 & 0.268 & 4.791 & 1.349 & 9.286 & 14.932 & 2548 & 4.312 \\
\hline 12 & 31 & Leather and leather products & 3.050 & 0.608 & 5.170 & 0.431 & 0.277 & 9.779 & 1.223 & -0.517 & 14.021 & 520 & 0.880 \\
\hline 13 & 32 & Stone, clay, glass, and concrete & 8.719 & 4.290 & 8.457 & 0.180 & 0.224 & 3.019 & 1.158 & 0.765 & 12.919 & 1759 & 2.977 \\
\hline 14 & 33 & Primary metal industries & 16.320 & 8.073 & 15.546 & 0.171 & 0.210 & 3.723 & 1.179 & -0.021 & 14.285 & 3097 & 5.241 \\
\hline 15 & 34 & Fabricated metal products & 6.169 & 1.852 & 7.232 & 0.264 & 0.255 & 5.311 & 1.263 & -0.868 & 13.167 & 3768 & 6.376 \\
\hline 16 & 35 & Machinery, except electrical & 7.111 & 1.791 & 7.704 & 0.054 & 0.332 & 6.296 & 1.635 & -0.789 & 16.197 & 9368 & 15.853 \\
\hline 17 & 36 & $\begin{array}{l}\text { Electrical and electronic machinery, } \\
\text { equipment and supplies }\end{array}$ & 6.409 & 1.752 & 6.899 & 0.078 & 0.342 & 6.054 & 1.737 & -2.516 & 17.886 & 297 & 0.503 \\
\hline 18 & 37 & Transportation equipment & 16.510 & 5.046 & 22.115 & 0.253 & 0.279 & 5.949 & 1.361 & 2.329 & 14.512 & 4041 & 6.838 \\
\hline 19 & 38 & $\begin{array}{l}\text { Instruments; Photographic, } \\
\text { medical and optical goods; Clocks }\end{array}$ & 5.620 & 1.442 & 5.667 & -0.105 & 0.337 & 6.196 & 2.066 & -0.763 & 17.318 & 7686 & 13.007 \\
\hline 20 & 39 & Miscellaneous manufacturing industries & 2.702 & 0.547 & 3.201 & 0.147 & 0.297 & 6.724 & 1.387 & -1.025 & 15.931 & 1757 & 2.973 \\
\hline
\end{tabular}

Notes: The sample comes from the COMPUSTAT database between fiscal year 1962 and 2006 and the CRSP database between calendar year 1962 and 2007. Variables are discussed and defined in Table 1: TA total assets in million U.S dollar units; K - capital stocks in million U.S. dollar units; S - net sales in million U.S. dollars; CFK - ratio of cash flow to capital stock; IK - ratio of investment ratio of sales to capital stock; TQ - Tobin's Q; R - annual stock returns in percentage; $\mathrm{s}$ - annual stock standard deviation in percentage. All accounting data are real that is deflated by GDP deflator based on January 1983 dollars. 
Table 3. Descriptive statistics over fiscal years

\begin{tabular}{|c|c|c|c|c|c|c|c|c|c|c|c|c|}
\hline Year & TAA & 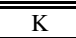 & 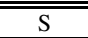 & CFF & $\overline{\mathrm{IIK}}$ & SK & 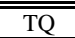 & $\mathrm{R}$ & $\mathrm{s}$ & pg & Number of observations & Percent of observations \\
\hline 1962 & "11.936 & 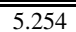 & 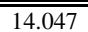 & 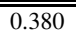 & (20.203 & (2.895 & 1.537 & 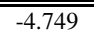 & $\begin{array}{l}10.874 \\
\end{array}$ & $\begin{array}{l}-0.100 \\
\end{array}$ & " 334 & cl. \\
\hline 1963 & 15.233 & 6.664 & 16.977 & 0.333 & 0.202 & 4.590 & 1.567 & 7.474 & 8.636 & -0.201 & 264 & 0.382 \\
\hline 1964 & 15.236 & 6.750 & 17.203 & 0.372 & 0.230 & 4.702 & 1.688 & 8.075 & 8.506 & -0.100 & 300 & 0.434 \\
\hline 1965 & 13.797 & 5.910 & 6.455 & 0.388 & 0.274 & 5.003 & 1.802 & 12.916 & 9.364 & -0.162 & 387 & 0.560 \\
\hline 1966 & 12.013 & 5.148 & 14.532 & 0.391 & 0.315 & 5.092 & 1.522 & -5.080 & 11.681 & -0.149 & 727 & 1.052 \\
\hline 1967 & 11.269 & 4.769 & 13.354 & 0.365 & 0.312 & 5.028 & 1.981 & 17.286 & 12.171 & -0.212 & 913 & 1.321 \\
\hline 1968 & 10.742 & 4.387 & 12.847 & 0.357 & 0.303 & 5.117 & 2.113 & 7.377 & 11.460 & -0.327 & 1070 & 1.548 \\
\hline 1969 & 9.955 & 4.065 & 11.503 & 0.318 & 0.322 & 5.065 & 1.657 & -15.046 & 12.345 & -0.082 & 1289 & 1.865 \\
\hline 1970 & 8.932 & 3.732 & 10.125 & 0.266 & 0.259 & 5.004 & 1.396 & -8.559 & 15.208 & 0.091 & 1519 & 2.198 \\
\hline 1971 & 8.718 & 3.579 & 9.858 & 0.261 & 0.227 & 5.061 & 1.598 & 3.814 & 13.760 & -0.163 & 1640 & 2.373 \\
\hline 1972 & 8.375 & 3.371 & 9.859 & 0.324 & 0.267 & 5.274 & 1.593 & -0.515 & 12.576 & -0.276 & 1700 & 2.460 \\
\hline 1973 & 8.665 & 3.309 & 10.837 & 0.348 & 0.308 & 5.571 & 1.183 & -20.973 & 15.154 & 1.335 & 1735 & 2.510 \\
\hline 1974 & 9.060 & 3.365 & 11.954 & 0.323 & 0.297 & 5.734 & 0.933 & -14.454 & 15.581 & 3.108 & 1659 & 2.400 \\
\hline 1975 & 8.518 & 3.302 & 11.047 & 0.320 & 0.242 & 5.603 & 1.022 & 14.583 & 14.777 & 0.618 & 1739 & 2.516 \\
\hline 1976 & 8.779 & 3.379 & 11.652 & 0.350 & 0.266 & 5.762 & 1.075 & 11.950 & 12.854 & -1.042 & 1735 & 2.510 \\
\hline 1977 & 9.100 & 3.481 & 12.173 & 0.342 & 0.292 & 5.812 & 1.052 & 0.673 & 11.546 & 0.074 & 1684 & 2.437 \\
\hline 1978 & 9.155 & 3.430 & 12.441 & 0.358 & 0.321 & 6.001 & 1.105 & 1.806 & 13.035 & -0.609 & 1713 & 2.479 \\
\hline 1979 & 8.966 & 3.343 & 12.444 & 0.339 & 0.344 & 5.985 & 1.189 & 7.452 & 12.638 & 4.472 & 1709 & 2.473 \\
\hline 1980 & 9.082 & 3.485 & 12.338 & 0.278 & 0.340 & 5.916 & 1.389 & 5.966 & 14.216 & 0.760 & 1718 & 2.486 \\
\hline 1981 & 8.999 & 3.556 & 11.958 & 0.257 & 0.341 & 5.858 & 1.304 & -1.224 & 12.917 & -0.628 & 1808 & 2.616 \\
\hline 1982 & 8.360 & 3.355 & 10.504 & 0.180 & 0.300 & 5.384 & 1.489 & 7.182 & 13.548 & -1.047 & 1762 & 2.549 \\
\hline 1983 & 8.674 & 3.482 & 10.633 & 0.195 & 0.288 & 5.417 & 1.672 & 8.450 & 12.782 & -1.103 & 1824 & 2.639 \\
\hline 1984 & 8.473 & 3.336 & 10.596 & 0.139 & 0.348 & 5.459 & 1.478 & -7.653 & 13.084 & -0.744 & 1868 & 2.703 \\
\hline 1985 & 7.775 & 3.067 & 9.340 & 0.048 & 0.331 & 5.243 & $\begin{array}{l}1.667 \\
\end{array}$ & 6.737 & 13.590 & -0.874 & 1866 & 2.700 \\
\hline 1986 & 8.050 & 3.072 & 9.175 & 0.054 & 0.318 & 5.248 & 1.689 & -0.233 & 15.215 & -4.657 & 1874 & 2.712 \\
\hline 1987 & 9.061 & 3.415 & 10.347 & 0.049 & 0.316 & 5.395 & 1.558 & -0.819 & 17.175 & 1.124 & 1872 & 2.709 \\
\hline 1988 & 9.396 & 3.457 & 10.677 & 0.000 & 0.323 & 5.601 & 1.598 & 6.293 & 15.136 & -1.965 & 1825 & 2.641 \\
\hline 1989 & 9.896 & 3.701 & 11.237 & $\begin{array}{l}-0.009 \\
-\end{array}$ & 0.294 & 5.587 & 1.638 & 2.610 & 14.174 & 2.562 & 1718 & 2.486 \\
\hline 1990 & 10.110 & 3.773 & 11.163 & 0.037 & 0.298 & 5.579 & 1.505 & -7.582 & 15.710 & 1.467 & 1684 & 2.437 \\
\hline 1991 & 9.920 & 3.719 & 10.611 & 0.090 & 0.245 & 5.561 & 1.767 & 13.083 & 16.296 & -3.576 & 1654 & 2.393 \\
\hline 1992 & 10.235 & 3.871 & 0.743 & 0.112 & 0.272 & 5.455 & 1.780 & 7.705 & 16.391 & -0.658 & 1724 & 2.494 \\
\hline 1993 & 10.047 & 3.729 & 10.237 & 0.104 & 0.290 & 5.537 & 1.912 & 6.996 & 16.932 & -2.989 & 1790 & 2.590 \\
\hline 1994 & 9.583 & 3.485 & 9.866 & 0.051 & 0.312 & 5.527 & 1.771 & 0.963 & 16.633 & 1.564 & 1913 & 2.768 \\
\hline 1995 & 9.954 & 3.549 & 10.441 & 0.135 & 0.319 & 5.523 & 1.959 & 6.821 & 16.499 & 0.695 & 1984 & 2.871 \\
\hline 1996 & 9.976 & 3.648 & 10.251 & 0.055 & 0.323 & 5.477 & 1.920 & 3.618 & 17.065 & 2.038 & 2053 & 2.970 \\
\hline 1997 & 9.789 & 3.628 & 9.939 & -0.028 & 0.316 & 5.447 & 1.996 & 1.731 & 16.956 & -3.290 & 2109 & 3.052 \\
\hline 1998 & 10.514 & 3.705 & 10.135 & -0.133 & 0.298 & 5.327 & 1.781 & -8.230 & 17.920 & -4.601 & 2022 & 2.926 \\
\hline 1999 & 11.451 & 3.910 & 10.910 & -0.096 & 0.255 & 5.180 & 1.983 & -3.132 & 18.417 & 7.705 & 1871 & 2.707 \\
\hline 2000 & 11.638 & 3.803 & 11.254 & -0.221 & 0.268 & 5.298 & 1.846 & -13.108 & 20.530 & -0.074 & 1734 & 2.509 \\
\hline 2001 & 12.612 & 4.007 & 11.522 & -0.317 & 0.231 & 5.197 & 1.823 & -0.097 & 18.233 & -3.956 & 1592 & 2.303 \\
\hline 2002 & 12.521 & 4.019 & 11.560 & -0.253 & 0.197 & 5.169 & 1.581 & -7.084 & 18.157 & 4.110 & 1535 & 2.221 \\
\hline 2003 & 13.457 & 4.117 & 12.474 & -0.109 & 0.190 & 5.508 & 2.019 & 12.642 & 15.552 & 0.466 & 1503 & 2.175 \\
\hline 2004 & 15.047 & 4.373 & 14.264 & 0.002 & 0.216 & 5.739 & 1.959 & 4.983 & 14.537 & 1.082 & 1402 & 2.029 \\
\hline 2005 & 16.111 & 4.430 & 15.374 & 0.032 & 0.241 & 5.882 & 1.986 & -3.044 & 13.304 & 2.987 & 1290 & 1.867 \\
\hline 2006 & 16.062 & 3.963 & 15.624 & 0.067 & 0.265 & 6.014 & 2.019 & 5.922 & 12.935 & 0.421 & 1001 & 1.448 \\
\hline Average/Total & 10.561 & 3.931 & 11.388 & 0.152 & 0.283 & 5.418 & 1.624 & 1.634 & 14.357 & 0.069 & 69113 & 100 \\
\hline
\end{tabular}

Notes: The sample comes from the COMPUSTAT database between fiscal year 1962 and 2006 and the CRSP database between calendar year 1962 and 2007. Variables are discussed and defined in Table A-1: TA - total assets in million U.S dollar units; K - capital stocks in million U.S. dollar units; S - net sales in million U.S. dollars; CFK - ratio of cash flow to capital stock; IK - ratio of investment to capital stock (t-1); SK: ratio of sales to capital stock; TQ - Tobin's Q; R - annual stock 
Table 4. OLS estimates of S\&P 500 volatilities on crude oil prices

\begin{tabular}{|c|c|c|c|c|}
\hline Dependent variables: ( $S \& P 500$ volatility) & $(1)$ & $(2)$ & $(3)$ & $(4)$ \\
\hline Intercept & $\begin{array}{l}3.657 \text { *** } \\
(18.03)\end{array}$ & $\begin{array}{l}4.816 * * * \\
(31.74)\end{array}$ & $\begin{array}{l}4.847 \text { **** } \\
(32.62)\end{array}$ & $\begin{array}{l}4.889 \text { *** } \\
(33.32)\end{array}$ \\
\hline$p g_{t}$ & $\begin{array}{l}0.062 * * * \\
(8.65)\end{array}$ & & & \\
\hline$p g \max (6)_{t}$ & & $\begin{array}{l}0.023 * * * \\
(2.91)\end{array}$ & & \\
\hline $\operatorname{pgmax}(12)_{t}$ & & & $\begin{array}{l}0.023 * * * \\
(2.77)\end{array}$ & \\
\hline $\operatorname{pgmax}(24)_{t}$ & & & & $\begin{array}{l}0.020 * * * \\
(2.27)\end{array}$ \\
\hline Goodness of fit (R-Squared) & 0.114 & 0.014 & 0.013 & 0.009 \\
\hline
\end{tabular}

Notes: $p g_{t}$ is the monthly growth rate of real oil prices, and $p g \max (6)_{t}, \operatorname{pgmax}(12)_{t}$, and $p g \max (24)_{t}$, are the growth rate of real oil price, $p g_{t}$, if $p g_{t}$ is greater than the maximum of the last 6 , 12 , and 24 months, respectively, 0 otherwise. The dependent variable is the monthly $S \& P 500$ stock price volatility computed by using Baum et al.'s (2008) approach. ***,**,* are the significance levels at 1\%, 5\%, and $10 \%$, respectively. The values in the parenthesis are absolute t-statistics. 
Table 5. Least squares estimates using U.S. manufacturing company data

\begin{tabular}{|c|c|c|c|c|c|c|}
\hline \multirow{2}{*}{$\begin{array}{l}\text { Dependent variables: }\left(I_{i t} / K_{i t-1}\right) \\
\text { Lagged investment rate }\left(I_{i t-1} / K_{i t-2}\right)\end{array}$} & \multicolumn{2}{|l|}{$(1)$} & \multicolumn{2}{|c|}{$(2)$} & \multicolumn{2}{|c|}{ (3) } \\
\hline & $\begin{array}{r}0.359 \\
(99.21)\end{array}$ & $* * *$ & $\begin{array}{r}0.128 \\
(33.12)\end{array}$ & $* * *$ & $\begin{array}{r}0.132 \\
(34.50)\end{array}$ & $* * *$ \\
\hline Sales growth $\left(\Delta y_{i t}\right)$ & $\begin{array}{r}0.477 \\
(42.22)\end{array}$ & $* * *$ & $\begin{array}{r}0.288 \\
(26.31)\end{array}$ & $* * *$ & $\begin{array}{r}0.347 \\
(31.98)\end{array}$ & $* * *$ \\
\hline Cash flow $\left(C_{i t} / K_{i t-1}\right)$ & $\begin{array}{r}0.017 \\
(11.05)\end{array}$ & $* * *$ & $\begin{array}{r}0.018 \\
(10.78)\end{array}$ & $* * *$ & $\begin{array}{c}0.008 \\
(4.70)\end{array}$ & $* * *$ \\
\hline Lagged cash flow $\left(C_{i t-1} / K_{i t-2}\right)$ & $\begin{array}{r}0.035 \\
(23.31)\end{array}$ & $* * *$ & $\begin{array}{r}0.044 \\
(27.16)\end{array}$ & $* * *$ & $\begin{array}{r}0.036 \\
(22.66)\end{array}$ & $* * *$ \\
\hline Error correction term $(y-k)_{i t-1}$ & $\begin{array}{r}0.007 \\
(7.94)\end{array}$ & $* * *$ & $\begin{array}{r}0.119 \\
(64.30)\end{array}$ & $* * *$ & $\begin{array}{r}0.201 \\
(78.81)\end{array}$ & $* * *$ \\
\hline Sales growth squared $\left(\Delta y_{i t}\right)^{2}$ & $\begin{array}{r}0.027 \\
(10.75)\end{array}$ & $* * *$ & $\begin{array}{r}0.036 \\
(14.86)\end{array}$ & $* * *$ & $\begin{array}{r}0.042 \\
(17.49)\end{array}$ & $* * *$ \\
\hline Change in oil shocks $\left(\Delta o_{t}\right)$ & $\begin{array}{r}0.036 \\
(18.92)\end{array}$ & $* * *$ & $\begin{array}{r}0.004 \\
(2.01)\end{array}$ & $* *$ & $\begin{array}{r}0.006 \\
(1.00)\end{array}$ & \\
\hline Lagged oil shocks $\left(o_{t-1}\right)$ & $\begin{array}{r}0.066 \\
(25.24)\end{array}$ & $* * *$ & $\begin{array}{c}0.004 \\
(1.57)\end{array}$ & & $\begin{array}{c}0.013 \\
(1.96)\end{array}$ & $*$ \\
\hline Change in stock volatility $\left(\Delta s_{i t}\right)$ & $\begin{array}{r}0.003 \\
(14.06)\end{array}$ & $* * *$ & $\begin{array}{r}-0.001 \\
(5.94)\end{array}$ & $* * *$ & $\begin{array}{r}-0.002 \\
(6.37)\end{array}$ & $* * *$ \\
\hline Lagged stock volatility $\left(s_{i t-1}\right)$ & $\begin{array}{r}0.008 \\
(58.75)\end{array}$ & $* * *$ & $\begin{array}{r}-0.002 \\
(10.72)\end{array}$ & $* * *$ & $\begin{array}{r}-0.002 \\
(9.93)\end{array}$ & $* * *$ \\
\hline Change in interaction $\left(\Delta U_{i t}\right)$ & $\begin{array}{r}-0.171 \\
(19.37)\end{array}$ & $* * *$ & $\begin{array}{r}-0.020 \\
(2.30)\end{array}$ & $* *$ & $\begin{array}{r}-0.021 \\
(2.34)\end{array}$ & $*$ \\
\hline Lagged interaction $\left(U_{i t-1}\right)$ & $\begin{array}{r}-0.343 \\
(27.25)\end{array}$ & $* * *$ & $\begin{array}{r}-0.041 \\
(3.09)\end{array}$ & $* * *$ & $\begin{array}{r}-0.041 \\
(2.95)\end{array}$ & $* * *$ \\
\hline Oil shocks $*$ sales growth $\left(o_{t} * \Delta y_{i t}\right)$ & $\begin{array}{r}-0.076 \\
(9.38)\end{array}$ & $* * *$ & $\begin{array}{r}-0.025 \\
(3.27)\end{array}$ & $* * *$ & $\begin{array}{r}-0.031 \\
(4.07)\end{array}$ & $* * *$ \\
\hline Stock volatility $*$ sales growth $\left(s_{i t} * \Delta y_{i t}\right)$ & $\begin{array}{r}-0.011 \\
(22.45)\end{array}$ & $* * *$ & $\begin{array}{r}-0.003 \\
(6.79)\end{array}$ & $* * *$ & $\begin{array}{r}-0.004 \\
(9.38)\end{array}$ & $* * *$ \\
\hline Interaction $*$ sales growth $\left(U_{i t} * \Delta y_{i t}\right)$ & $\begin{array}{r}0.225 \\
(6.95)\end{array}$ & $* * *$ & $\begin{array}{c}0.068 \\
(2.21)\end{array}$ & $* *$ & $\begin{array}{r}0.099 \\
(3.27)\end{array}$ & $* * *$ \\
\hline Firm effect & no & & yes & & yes & \\
\hline Year effect & no & & no & & yes & \\
\hline Goodness of fit (R-squared) & 0.663 & & 0.414 & & 0.448 & \\
\hline
\end{tabular}

Notes: The oil price shock/uncertainty, denoted by the interaction term $U_{i t}$, is the product of the stock price volatility $\left(s_{i t}\right)$ and the oil price shock $\left(o_{t}\right), U_{i t}=s_{i t} \times o_{t}$, where the oil price shock is set equal to $\operatorname{pgmax}(12)_{t}$, the growth rate of real oil prices if the growth rate is greater than the maximum of the last 12 months, 0 otherwise. Column (1) contains the OLS estimates and columns (2) and (3) contain one-way and two-way fixed effect least squares estimates, respectively, that produce standard errors robust to heteroscedasticity. $* * *, * *, *$ denote the significant levels at $1 \%, 5 \%$, and $10 \%$, respectively. The values in the parentheses are absolute t-statistics. 
Table 6. GMM estimates of equation (7) using U.S. manufacturing company data

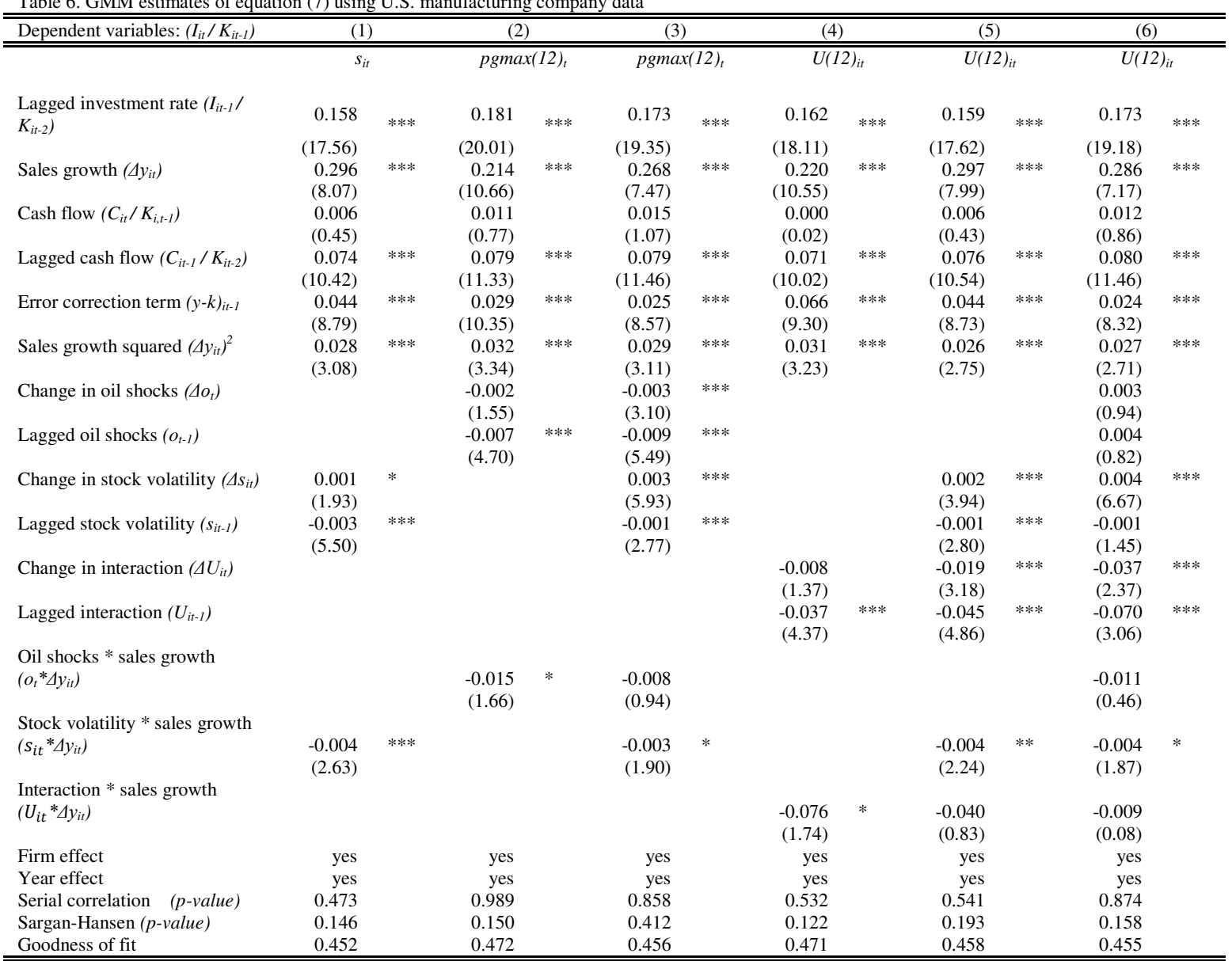

Notes: In column (1), $s_{i t}$ is firm $i$ 's stock price volatility in accounting year $t$ computed using Baum et al.'s (2008) approach that is described in Table 1. In columns (2)-(3), the oil price shock $o_{t}$ is set equal to $\operatorname{pgmax}(12)_{t}$ where $\operatorname{pgmax}(12)_{t}$ is equal to the growth rate of real oil price at time $t, p g_{t}$, if $p g_{t}$ is greater than the maximum growth rate of the last 12 months, zero otherwise. In columns (4)-(6), the oil price shock/uncertainty that firm $i$ is facing, denoted by the interaction term $U_{i t}$, which is set equal to $U(12)_{i t}=\operatorname{pgmax}(12)_{t} \times s_{i t}$ where $s_{i t}$ is the firm $i$ 's stock price volatility. The estimates are obtained by applying Arellano-Bond two-step system GMM method that produces heteroscedasticity robust standard errors. Sales, cash flows, stockvolatilities, and oil shocks are considered as endogenous, with the instruments in the first-differenced equations that are similar to Bloom et al. (2007): $I_{i, t}$.

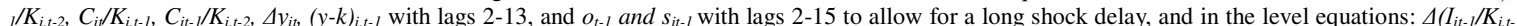
2), $\Delta \Delta y_{i t-1}, \Delta \Delta C_{i t-1} / K_{i, t-2}, \Delta \Delta(y-k)_{i,-l}, \Delta \Delta o_{t-l}, \Delta \Delta s_{i t-1}$ in the full model (6). The corresponding instrumental variables are not used when the endogenous variables do not appear in the models (1)-(5). Second-order serial correlation in the first-differenced residuals is tested using a Lagrange multiplier test (Arellano and Bond, 1991). Instrument validity is tested using a Sargan-Hansen test of the over-identifying restrictions. The goodness of fit measure is the squared correlation coefficient between actual and predicted levels of the dependent variable (Windmeijer, 1995). ***, **, * denote the significant levels at $1 \%, 5 \%$, and $10 \%$, respectively. The absolute t-values in parentheses are robust to autocorrelation and heteroscedasticity. Oil shock*stock volatility 
Table 7. GMM estimates of equation (7) using U.S. manufacturing company data

\begin{tabular}{|c|c|c|c|c|c|c|c|c|c|c|c|c|}
\hline \multirow{2}{*}{$\begin{array}{l}\text { Dependent variables: }\left(I_{i t} / K_{i t-1}\right) \\
\text { Lagged investment rate }\end{array}$} & \multicolumn{2}{|c|}{ (1) } & \multicolumn{2}{|c|}{ (2) } & \multicolumn{2}{|c|}{ (3) } & \multicolumn{2}{|c|}{ (4) } & \multicolumn{2}{|c|}{ (5) } & \multicolumn{2}{|c|}{ (6) } \\
\hline & pgmax & $2)^{01}{ }_{t}$ & $U(12$ & & $U(12$ & & $U(12$ & & $U(12$ & & $U(12)$ & ${ }_{i t}{ }_{i t}$ \\
\hline $\begin{array}{l}\text { Lagged investment rate } \\
\left(I_{i t-1} / K_{i t-2}\right)\end{array}$ & $\begin{array}{r}0.170 \\
(19.03)\end{array}$ & $* * *$ & $\begin{array}{r}0.161 \\
(17.98)\end{array}$ & $* * *$ & $\begin{array}{r}0.157 \\
(17.58)\end{array}$ & $* * *$ & $\begin{array}{r}0.170 \\
(18.78)\end{array}$ & $* * *$ & $\begin{array}{r}0.159 \\
(17.65)\end{array}$ & $* * *$ & $\begin{array}{r}0.159 \\
(17.73)\end{array}$ & $* * *$ \\
\hline Sales growth $\left(\Delta y_{i t}\right)$ & $\begin{array}{c}0.288 \\
(7.74)\end{array}$ & $* * *$ & $\begin{array}{r}0.227 \\
(10.51)\end{array}$ & $* * *$ & $\begin{array}{l}0.303 \\
(8.17)\end{array}$ & $* * *$ & $\begin{array}{l}0.267 \\
(6.05)\end{array}$ & $* * *$ & $\begin{array}{c}0.288 \\
(7.68)\end{array}$ & $* * *$ & $\begin{array}{c}0.289 \\
(7.74)\end{array}$ & $* * *$ \\
\hline Cash flow $\left(C_{i t} / K_{i t-1}\right)$ & $\begin{array}{c}0.015 \\
(1.11)\end{array}$ & & $\begin{array}{l}0.001 \\
(0.00)\end{array}$ & & $\begin{array}{c}0.007 \\
(0.47)\end{array}$ & & $\begin{array}{l}0.013 \\
(0.90)\end{array}$ & & $\begin{array}{c}0.007 \\
(0.51)\end{array}$ & & $\begin{array}{c}0.007 \\
(0.51)\end{array}$ & \\
\hline Lagged cash flow $\left(C_{i t-1} / K_{i t-2}\right)$ & $\begin{array}{r}0.077 \\
(11.21)\end{array}$ & $* * *$ & $\begin{array}{r}0.071 \\
(9.90)\end{array}$ & $* * *$ & $\begin{array}{r}0.075 \\
(10.38)\end{array}$ & $* * *$ & $\begin{array}{r}0.077 \\
(11.05)\end{array}$ & $* * *$ & $\begin{array}{r}0.076 \\
(10.55)\end{array}$ & $* * *$ & $\begin{array}{r}0.076 \\
(10.55)\end{array}$ & $* * *$ \\
\hline Error correction term $(y-k)_{i t-l}$ & $\begin{array}{r}0.030 \\
(9.71)\end{array}$ & $* * *$ & $\begin{array}{c}0.068 \\
(9.49)\end{array}$ & $* * *$ & $\begin{array}{l}0.046 \\
(9.04)\end{array}$ & $* * *$ & $\begin{array}{c}0.029 \\
(9.27)\end{array}$ & $* * *$ & $\begin{array}{l}0.044 \\
(8.64)\end{array}$ & $* * *$ & $\begin{array}{l}0.044 \\
(8.77)\end{array}$ & $* * *$ \\
\hline Sales growth squared $\left(\Delta y_{i t}\right)^{2}$ & $\begin{array}{c}0.030 \\
(3.12)\end{array}$ & $* * *$ & $\begin{array}{l}0.033 \\
(3.29)\end{array}$ & $* * *$ & $\begin{array}{c}0.028 \\
(2.93)\end{array}$ & $* * *$ & $\begin{array}{c}0.024 \\
(2.38)\end{array}$ & $* * *$ & $\begin{array}{l}0.027 \\
(2.83)\end{array}$ & $* * *$ & $\begin{array}{c}0.027 \\
(2.82)\end{array}$ & $* * *$ \\
\hline Change in oil shocks $\left(\Delta o_{t}^{O I}\right)$ & $\begin{array}{r}-0.077 \\
(5.82)\end{array}$ & $* * *$ & & & & & $\begin{array}{l}0.006 \\
(0.15)\end{array}$ & & & & & \\
\hline Lagged oil shocks $\left(o_{t-1}{ }^{0 I}\right)$ & $\begin{array}{r}-0.121 \\
(6.23)\end{array}$ & $* * *$ & & & & & $\begin{array}{c}0.068 \\
(1.18)\end{array}$ & & & & & \\
\hline Change in stock volatility $\left(\Delta s_{i t}\right)$ & $\begin{array}{c}0.003 \\
(5.70)\end{array}$ & $* * *$ & & & $\begin{array}{l}0.002 \\
(3.39)\end{array}$ & $* * *$ & $\begin{array}{c}0.004 \\
(6.44)\end{array}$ & $* * *$ & $\begin{array}{r}0.003 \\
(4.34)\end{array}$ & **** & $\begin{array}{r}0.003 \\
(4.36)\end{array}$ & $* * *$ \\
\hline Lagged stock volatility $\left(s_{i t-1}\right)$ & $\begin{array}{r}-0.002 \\
(4.17)\end{array}$ & $* * *$ & & & $\begin{array}{c}-0.002 \\
(4.01)\end{array}$ & $* * *$ & $\begin{array}{r}-0.001 \\
(1.28)\end{array}$ & & $\begin{array}{r}-0.001 \\
(2.64)\end{array}$ & $* * *$ & $\begin{array}{r}-0.001 \\
(2.63)\end{array}$ & $* * *$ \\
\hline Change in interaction $\left(\Delta U_{i t}\right)$ & & & & & & & & & $\begin{array}{r}-0.002 \\
(0.29)\end{array}$ & & $\begin{array}{r}-0.003 \\
(0.31)\end{array}$ & \\
\hline Lagged interaction $\left(U_{i t-1}\right)$ & & & & & & & & & $\begin{array}{r}-0.034 \\
(2.87)\end{array}$ & $* * *$ & $\begin{array}{r}-0.034 \\
(3.31)\end{array}$ & $* * *$ \\
\hline Change in interaction $\left(\Delta U_{i t}{ }^{O I}\right)$ & & & $\begin{array}{r}-0.002 \\
(2.02)\end{array}$ & $* *$ & $\begin{array}{r}-0.003 \\
(3.41)\end{array}$ & $* * *$ & $\begin{array}{r}-0.006 \\
(2.62)\end{array}$ & $* * *$ & $\begin{array}{r}-0.003 \\
(3.03)\end{array}$ & $* * *$ & & \\
\hline Lagged interaction $\left(U_{i t-1}{ }^{0 l}\right)$ & & & $\begin{array}{r}-0.004 \\
(3.63)\end{array}$ & $* * *$ & $\begin{array}{r}-0.005 \\
(3.98)\end{array}$ & $* * *$ & $\begin{array}{r}-0.013 \\
(3.93)\end{array}$ & $* * *$ & $\begin{array}{r}-0.003 \\
(2.10)\end{array}$ & $* *$ & & \\
\hline Interaction $\left(U_{i t}{ }^{0 l}\right)$ & & & & & & & & & & & $\begin{array}{r}-0.003 \\
(3.13)\end{array}$ & $* * *$ \\
\hline $\begin{array}{l}\text { Oil shocks * sales growth } \\
\left(o_{t}^{01} \Delta y_{i t}\right)\end{array}$ & $\begin{array}{c}0.127 \\
(1.14)\end{array}$ & & & & & & $\begin{array}{c}0.432 \\
(1.45)\end{array}$ & & & & & \\
\hline $\begin{array}{l}\text { Stock volatility * sales growth } \\
\left(s_{i, t} * \Delta y_{i t}\right)\end{array}$ & $\begin{array}{r}-0.004 \\
(2.70)\end{array}$ & $* * *$ & & & $\begin{array}{r}-0.004 \\
(2.51)\end{array}$ & $* * *$ & $\begin{array}{r}-0.002 \\
(1.14)\end{array}$ & & $\begin{array}{r}-0.004 \\
(2.22)\end{array}$ & $* *$ & $\begin{array}{r}-0.004 \\
(2.25)\end{array}$ & $* *$ \\
\hline $\begin{array}{l}\text { Interaction * sales growth } \\
\left(U_{i, t} * \Delta y_{i t}\right)\end{array}$ & & & & & & & & & $\begin{array}{r}-0.085 \\
(1.17)\end{array}$ & & $\begin{array}{r}-0.084 \\
(1.16)\end{array}$ & \\
\hline $\begin{array}{l}\text { Interaction * sales growth } \\
\left(U_{i, t}{ }^{0 l} * \Delta y_{i t}\right)\end{array}$ & & & $\begin{array}{r}-0.007 \\
(1.26)\end{array}$ & & $\begin{array}{r}-0.001 \\
(0.10)\end{array}$ & & $\begin{array}{r}-0.021 \\
(1.45)\end{array}$ & & $\begin{array}{l}0.007 \\
(0.84)\end{array}$ & & $\begin{array}{r}0.007 \\
(0.83)\end{array}$ & \\
\hline Firm effect & Yes & & yes & & yes & & yes & & yes & & yes & \\
\hline Year effect & Yes & & yes & & yes & & yes & & yes & & yes & \\
\hline Serial correlation $\quad(p$-value $)$ & 0.765 & & 0.520 & & 0.482 & & 0.759 & & 0.508 & & 0.513 & \\
\hline Sargan-Hansen ( $p$-value) & 0.593 & & 0.145 & & 0.223 & & 0.133 & & 0.227 & & 0.228 & \\
\hline Goodness of fit & 0.456 & & 0.472 & & 0.455 & & 0.454 & & 0.457 & & 0.457 & \\
\hline
\end{tabular}

Notes: In columns (1)-(6), the oil price shock $o_{t}^{01}$ is set equal to an indicator function, $p g \max (12)_{t}^{01}$, where $\operatorname{pgmax}(12)_{t}^{01}$ is equal to 1 if the growth rate of real oil price at time $t, p g_{t}$, is greater than the maximum growth rate of the last 12 months and zero otherwise, and $s_{i t}$ is firm $i$ 's stock price volatility in accounting year $t$ computed using Baum et al.'s (2008) approach that is described in Table 1. In columns (2)-(6), the oil price shock/uncertainty that firm $i$ is facing, denoted by the interaction term $U_{i t}$, is set equal to $U_{i t}=\operatorname{pgmax}(12)_{t} \times s_{i t}$ where $p g \max (12)_{t}$ is equal to the growth rate of real oil price at time $\mathrm{t}, p g_{t}$, if $p g_{t}$ is greater than the maximum growth rates of the last 12 months and zero otherwise, and the interaction term $U_{i t}^{01}$ is set equal to $U_{i t}^{01}=\operatorname{pgmax}(12)_{t}^{01} \times s_{i t}$. The estimates are obtained by applying Arellano-Bond two-step system GMM method that produces heteroscedasticity robust standard errors. Sales, cash flows, stock-volatilities, and oil shocks are considered as endogenous, with the instruments in the first-differenced equations that are similar to Bloom et al. (2007): $I_{i t-1} / K_{i t-2}, C_{i t} / K_{i t-1}, C_{i t-1} / K_{i t-2}, \Delta y_{i t},(y-k)_{i t-1}$ with lags $2-13$, and $o_{t-1}$, $o_{t-1}^{01}$ and $s_{i t-1}$ with lags 2-15 to allow for long shock delays, and in the level equations: $\Delta\left(I_{i t-1} / K_{i t-2}\right), \Delta \Delta y_{i t-1}, \Delta \Delta C_{i t-1} / K_{i t-2}, \Delta \Delta(y-k)_{i t-l}, \Delta \Delta o_{t-1}, \Delta \Delta o_{t-1}^{01}, \Delta \Delta s_{i t-l}$. The corresponding instrumental variables are not used when the endogenous variables do not appear in the models. Second-order serial correlation in the first-differenced residuals is tested using a Lagrange multiplier test (Arellano and Bond, 1991). Instrument validity is tested using a Sargan-Hansen test of the overidentifying restrictions. The goodness of fit measure is the squared correlation coefficient between actual and predicted levels of the dependent variable (Windmeijer, 1995). ***, **, * denote the significant levels at $1 \%, 5 \%$, and $10 \%$, respectively. The absolute $\mathrm{t}$-values in parentheses are robust to autocorrelation and heteroscedasticity. 
Table 8. Oil price shock/uncertainty effects on firm investment stimulus policy

\begin{tabular}{|c|c|c|c|c|}
\hline \multirow{3}{*}{$\begin{array}{l}\text { Dependent variables: }\left(I_{i t} / K_{i t-1}\right) \\
\text { Lagged investment rate }\left(I_{i t-1} / K_{i t-2}\right)\end{array}$} & \multicolumn{2}{|c|}{$(1)$} & \multicolumn{2}{|c|}{$(2)$} \\
\hline & \multicolumn{2}{|c|}{$U(12)_{i t}$} & \multicolumn{2}{|c|}{$U(12)_{i t}^{01}$} \\
\hline & $\begin{array}{r}0.157 \\
(17.54)\end{array}$ & $* * *$ & $\begin{array}{r}0.158 \\
(17.50)\end{array}$ & $* * *$ \\
\hline Sales growth $\left(\Delta y_{i t}\right)$ & $\begin{array}{r}0.297 \\
(8.07)\end{array}$ & $* * *$ & $\begin{array}{r}0.301 \\
(8.18)\end{array}$ & $* * *$ \\
\hline Cash flow $\left(C_{i t} / K_{i t-1}\right)$ & $\begin{array}{r}0.005 \\
(0.38)\end{array}$ & & $\begin{array}{l}0.006 \\
(0.44)\end{array}$ & \\
\hline Lagged cash flow $\left(C_{i t-1} / K_{i t-2}\right)$ & $\begin{array}{r}0.075 \\
(10.50)\end{array}$ & $* * *$ & $\begin{array}{r}0.074 \\
(10.42)\end{array}$ & $* * *$ \\
\hline Error correction term $(y-k)_{i t-1}$ & $\begin{array}{r}0.044 \\
(8.88)\end{array}$ & $* * *$ & $\begin{array}{r}0.044 \\
(8.76)\end{array}$ & $* * *$ \\
\hline Sales growth squared $\left(\Delta y_{i t}\right)^{2}$ & $\begin{array}{l}0.026 \\
(2.86)\end{array}$ & $* * *$ & $\begin{array}{l}0.026 \\
(2.91)\end{array}$ & $* * *$ \\
\hline Change in stock volatility $\left(\Delta s_{i t}\right)$ & $\begin{array}{l}0.001 \\
(2.30)\end{array}$ & $* *$ & $\begin{array}{l}0.001 \\
(2.13)\end{array}$ & $* *$ \\
\hline Lagged stock volatility $\left(s_{i t-1}\right)$ & $\begin{array}{r}-0.002 \\
(5.09)\end{array}$ & $* * *$ & $\begin{array}{r}-0.003 \\
(5.41)\end{array}$ & $* * *$ \\
\hline Stock volatility $*$ sales growth $\left(s_{i t} * \Delta y_{i t}\right)$ & $\begin{array}{r}-0.003 \\
(2.04)\end{array}$ & $* *$ & $\begin{array}{r}-0.004 \\
(2.32)\end{array}$ & $* *$ \\
\hline Interaction $*$ sales growth $\left(U_{i t} * \Delta y_{i t}\right)$ & $\begin{array}{r}-0.079 \\
(1.89)\end{array}$ & $*$ & $\begin{array}{r}-0.006 \\
(1.14)\end{array}$ & \\
\hline Firm effect & yes & & yes & \\
\hline Year effect & yes & & yes & \\
\hline Serial correlation $(p$-value $)$ & 0.498 & & 0.497 & \\
\hline Sargan-Hansen ( $p$-value) & 0.174 & & 0.141 & \\
\hline Goodness of fit & 0.454 & & 0.453 & \\
\hline
\end{tabular}

Notes: In column (1), the oil price shock/uncertainty that firm $i$ is facing, denoted by the interaction term $U_{i t}$, is set equal to $U(12)_{i t}=\operatorname{pgmax}(12)_{t} \times s_{i t}$ where $\operatorname{pgmax}(12)_{t}$ is equal to the growth rate of real oil price at time $t, p g_{t}$, if $p g_{t}$ is greater than the maximum growth rate of the last 12 months, zero otherwise, and $s_{i t}$ is the firm $i$ 's stock price volatility. In column (2), the oil price shock/uncertainty that firm $i$ is facing, denoted by the interaction term $U_{i t}$, is set equal to $U(12)_{i t}^{01}=\operatorname{pg\operatorname {max}}(12)_{t}^{01} \times s_{i t}$ where $\operatorname{pg} \max (12)_{t}^{01}$ is equal to 1 if the growth rate of real oil price at time $t, p g_{t}$, is greater than the maximum growth rate of the last 12 months and zero otherwise. The estimates are obtained by applying Arellano-Bond two-step system GMM method that produces heteroscedasticity robust standard errors. Sales, cash flows, and stockvolatilities are considered as endogenous, with the instruments in the first-differenced equations that are similar to Bloom et al. (2007): $I_{i, t-1} / K_{i, t-2}, C_{i t} / K_{i, t-1}, C_{i t-1} / K_{i, t-2}, \Delta y_{i t},(y-k)_{i, t-1}$ with lags 2-15, and $s_{i t-1}$ with lags 217 to allow for a long shock delay, and in the level equations: $\Delta\left(I_{i t-1} / K_{i, t-2}\right), \Delta \Delta y_{i t-1}, \Delta \Delta C_{i t-1} / K_{i, t-2}, \Delta \Delta(y-k)_{i, t-1}$, $\Delta \Delta s_{i t-1}$. Second-order serial correlation in the first-differenced residuals is tested using a Lagrange multiplier test (Arellano and Bond, 1991). Instrument validity is tested using a Sargan-Hansen test of the over-identifying restrictions. The goodness of fit measure is the squared correlation coefficient between actual and predicted levels of the dependent variable (Windmeijer, 1995). ***, **, * denote the significant levels at $1 \%, 5 \%$, and $10 \%$, respectively. The absolute t-values in parentheses are robust to autocorrelation and heteroscedasticity. 
Table 9. Estimates using CPI and PPI deflators for real oil prices

\begin{tabular}{|c|c|c|c|c|c|c|c|c|}
\hline \multirow{3}{*}{$\begin{array}{l}\text { Dependent variables: }\left(I_{i t} / K_{i t-1}\right) \\
\text { Lagged investment rate }\left(I_{i t-1} / K_{i t-2}\right)\end{array}$} & \multicolumn{2}{|c|}{$(1)$} & \multicolumn{2}{|c|}{$(2)$} & \multicolumn{2}{|c|}{ (3) } & \multicolumn{2}{|c|}{$(4)$} \\
\hline & \multicolumn{2}{|c|}{$p g_{t}^{C P I} \times s_{i t}$} & \multicolumn{2}{|c|}{$p g_{t}^{P P I} \times s_{i t}$} & \multicolumn{2}{|c|}{$\overline{p g \max }(12)_{t}^{P P I} \times s_{i t}$} & \multicolumn{2}{|c|}{$\overline{p g \max }(12)_{t}^{P P I 01} \times s_{i t}$} \\
\hline & $\begin{array}{r}0.168 \\
(18.54)\end{array}$ & $* * *$ & $\begin{array}{r}0.170 \\
(18.70)\end{array}$ & $* * *$ & $\begin{array}{r}0.172 \\
(19.08)\end{array}$ & $* * *$ & $\begin{array}{r}0.171 \\
(18.74)\end{array}$ & $* * *$ \\
\hline Sales growth $\left(\Delta y_{i t}\right)$ & $\begin{array}{l}0.296 \\
(8.23)\end{array}$ & $* * *$ & $\begin{array}{r}0.281 \\
(7.61)\end{array}$ & $* * *$ & $\begin{array}{l}0.279 \\
(6.82)\end{array}$ & $* * *$ & $\begin{array}{r}0.245 \\
(5.54)\end{array}$ & $* * *$ \\
\hline Cash flow $\left(C_{i t} / K_{i t-1}\right)$ & $\begin{array}{l}0.012 \\
(0.85)\end{array}$ & & $\begin{array}{r}0.012 \\
(0.84)\end{array}$ & & $\begin{array}{r}0.012 \\
(0.84)\end{array}$ & & $\begin{array}{r}0.009 \\
(0.63)\end{array}$ & \\
\hline Lagged cash flow $\left(C_{i t-1} / K_{i t-2}\right)$ & $\begin{array}{r}0.080 \\
(11.43)\end{array}$ & $* * *$ & $\begin{array}{r}0.079 \\
(11.38)\end{array}$ & $* * *$ & $\begin{array}{r}0.081 \\
(11.53)\end{array}$ & $* * *$ & $\begin{array}{r}0.081 \\
(11.35)\end{array}$ & $* * *$ \\
\hline Error correction term $(y-k)_{i t-1}$ & $\begin{array}{l}0.027 \\
(8.54)\end{array}$ & $* * *$ & $\begin{array}{r}0.028 \\
(8.74)\end{array}$ & $* * *$ & $\begin{array}{r}0.025 \\
(8.70)\end{array}$ & $* * *$ & $\begin{array}{r}0.028 \\
(9.11)\end{array}$ & $* * *$ \\
\hline Sales growth squared $\left(\Delta y_{i t}\right)^{2}$ & $\begin{array}{l}0.029 \\
(2.92)\end{array}$ & $* * *$ & $\begin{array}{l}0.029 \\
(3.03)\end{array}$ & $* * *$ & $\begin{array}{l}0.027 \\
(2.63)\end{array}$ & $* * *$ & $\begin{array}{l}0.027 \\
(2.56)\end{array}$ & $* * *$ \\
\hline Change in oil shocks $\left(\Delta o_{t}\right)$ & $\begin{array}{l}0.001 \\
(0.02)\end{array}$ & & $\begin{array}{l}0.001 \\
(0.51)\end{array}$ & & $\begin{array}{l}0.004 \\
(1.18)\end{array}$ & & $\begin{array}{r}-0.002 \\
(0.08)\end{array}$ & \\
\hline Lagged oil shocks $\left(o_{t-1}\right)$ & $\begin{array}{l}0.001 \\
(0.80)\end{array}$ & & $\begin{array}{l}0.002 \\
(0.17)\end{array}$ & & $\begin{array}{l}0.004 \\
(0.94)\end{array}$ & & $\begin{array}{l}0.000 \\
(0.23)\end{array}$ & \\
\hline Change in stock volatility $\left(\Delta s_{i t}\right)$ & $\begin{array}{r}0.003 \\
(5.13)\end{array}$ & $* * *$ & $\begin{array}{r}0.002 \\
(4.90)\end{array}$ & $* * *$ & $\begin{array}{l}0.004 \\
(6.86)\end{array}$ & $* * *$ & $\begin{array}{r}0.003 \\
(5.15)\end{array}$ & $* * *$ \\
\hline Lagged stock volatility $\left(s_{i t-1}\right)$ & $\begin{array}{r}-0.002 \\
(4.06)\end{array}$ & $* * *$ & $\begin{array}{r}-0.002 \\
(4.30)\end{array}$ & $* * *$ & $\begin{array}{r}-0.001 \\
(0.83)\end{array}$ & & $\begin{array}{l}-0.001 \\
(3.25)\end{array}$ & $* * *$ \\
\hline Change in interaction $\left(\Delta U_{i t}\right)$ & $\begin{array}{r}-0.007 \\
(1.08)\end{array}$ & & $\begin{array}{r}-0.010 \\
(1.45)\end{array}$ & & $\begin{array}{r}-0.037 \\
(2.39)\end{array}$ & $* * *$ & $\begin{array}{r}-0.003 \\
(2.56)\end{array}$ & $* * *$ \\
\hline Lagged interaction $\left(U_{i t-1}\right)$ & $\begin{array}{r}-0.017 \\
(1.78)\end{array}$ & $*$ & $\begin{array}{r}-0.022 \\
(2.13)\end{array}$ & $* *$ & $\begin{array}{l}-0.069 \\
(3.00)\end{array}$ & $* * *$ & $\begin{array}{r}-0.006 \\
(4.31)\end{array}$ & $* * *$ \\
\hline Oil shocks * sales growth $\left(o_{t}{ }^{*} \Delta y_{i t}\right)$ & $\begin{array}{r}0.012 \\
(1.26)\end{array}$ & & $\begin{array}{r}0.012 \\
(1.22)\end{array}$ & & $\begin{array}{r}-0.011 \\
(0.45)\end{array}$ & & $\begin{array}{l}0.490 \\
(1.86)\end{array}$ & * \\
\hline $\begin{array}{l}\text { Stock volatility * sales growth } \\
\left(s_{i, t} * 4 y_{i t}\right)\end{array}$ & $\begin{array}{r}-0.004 \\
(2.34)\end{array}$ & $* * *$ & $\begin{array}{r}-0.003 \\
(2.06)\end{array}$ & ** & $\begin{array}{r}-0.003 \\
(1.52)\end{array}$ & & $\begin{array}{r}-0.002 \\
(0.78)\end{array}$ & \\
\hline Interaction * sales growth $\left(U_{i t} * \Delta y_{i t}\right)$ & $\begin{array}{r}-0.093 \\
(2.09)\end{array}$ & $* *$ & $\begin{array}{r}-0.092 \\
(2.00)\end{array}$ & $* *$ & $\begin{array}{r}-0.043 \\
(0.38)\end{array}$ & & $\begin{array}{r}-0.023 \\
(1.66)\end{array}$ & \\
\hline Firm effect & yes & & yes & & yes & & yes & \\
\hline Year effect & yes & & yes & & yes & & yes & \\
\hline Serial correlation (p-value) & 0.678 & & 0.706 & & 0.890 & & 0.823 & \\
\hline Sargan-Hansen (p-value) & 0.193 & & 0.189 & & 0.196 & & 0.218 & \\
\hline Goodness of fit & 0.453 & & 0.453 & & 0.456 & & 0.454 & \\
\hline
\end{tabular}

Notes: In column (1), the oil price shock $o_{t}$ is set equal to the growth rate of real oil price at time $t, p g_{t}^{c p i}$, that is obtained using nominal oil prices deflated by the U.S. CPI and $s_{i t}$ is firm $i$ 's stock price volatility in accounting year $t$ computed using Baum et al.'s (2008) approach that is described in Table 1. The oil price shock/uncertainty that firm $i$ is facing, denoted by the interaction term $U_{i t}$, is set equal to $U_{i t}=p g_{t}^{c p i} \times s_{i t}$. In column (2), the oil price shock $o_{t}$ is set equal to the growth rate of real oil price at time $t, p g_{t}^{p p i}$, that is obtained using nominal oil prices deflated by the U.S. PPI. The oil price shock/uncertainty that firm $i$ is facing, denoted by the interaction term $U_{i t}$, is set equal to $U_{i t}=p g_{t}^{p p i} \times s_{i t}$. In column (3), the oil price shock $o_{t}$ is set equal to $\operatorname{pgmax}(12)_{t}^{P P I}$ that is equal to the growth rate of real oil price at time $t, p g_{t}^{p p i}$, if $p g_{t}^{p p i}$ is greater than the maximum growth rate of the last 12 months and zero otherwise. The oil price shock/uncertainty that firm $i$ is facing, $U_{i t}$, is set equal to $U_{i t}=\operatorname{pgmax}(12)_{t}^{p p i} \times s_{i t}$. In column (4), the oil price shock $o_{t}$ is set equal to $\operatorname{pgmax}(12)_{t}^{P P I 01}$ that is equal to 1 if the growth rate of real oil price at time t, $p g_{t}^{p p i}$, is greater than the maximum growth rate of the last 12 months and zero otherwise. The oil price shock/uncertainty that firm $i$ is facing, $U_{i t}$, is set equal to $U_{i t}=\operatorname{pg\operatorname {max}}(12)_{t}^{\text {ppio1 }} \times s_{i t}$. The estimates are obtained by applying Arellano-Bond two-step system GMM method that produces heteroscedasticity robust standard errors. Sales, cash flows, stock-volatilities, and oil shocks are considered as endogenous, with the instruments in the first-differenced equations that are similar to Bloom et al. (2007): $I_{i, t-1} / K_{i, t-2}, C_{i /} / K_{i, t-1}, C_{i t-1} / K_{i, t-2}, \Delta y_{i t,},(y-k)_{i, t-1}$ with lags 2-13, and $o_{t-1}$ and $s_{i t-1}$ with lags 2-15 to allow for a long shock delay, and in the level equations: $\Delta\left(I_{i t-1} / K_{i, t-2}\right), \Delta \Delta y_{i t-l}, \Delta \Delta C_{i t-}$ ${ }_{l} / K_{i, t-2}, \Delta \Delta(y-k)_{i, t-1}, \Delta \Delta o_{t-1}, \Delta \Delta s_{i t-1}$. Second-order serial correlation in the first-differenced residuals is tested using a Lagrange multiplier test (Arellano and Bond, 1991). Instrument validity is tested using a Sargan-Hansen test of the over-identifying restrictions. The goodness of fit measure is the squared correlation coefficient between actual and predicted levels of the dependent variable (Windmeijer, 1995). $* * *, * *, *$ denote the significant levels at $1 \%, 5 \%$, and $10 \%$, respectively. The absolute t-values in parentheses are robust to autocorrelation and heteroscedasticity. 
Figure 1: Real Price of Crude Oil, 1971.1 - 2007.12

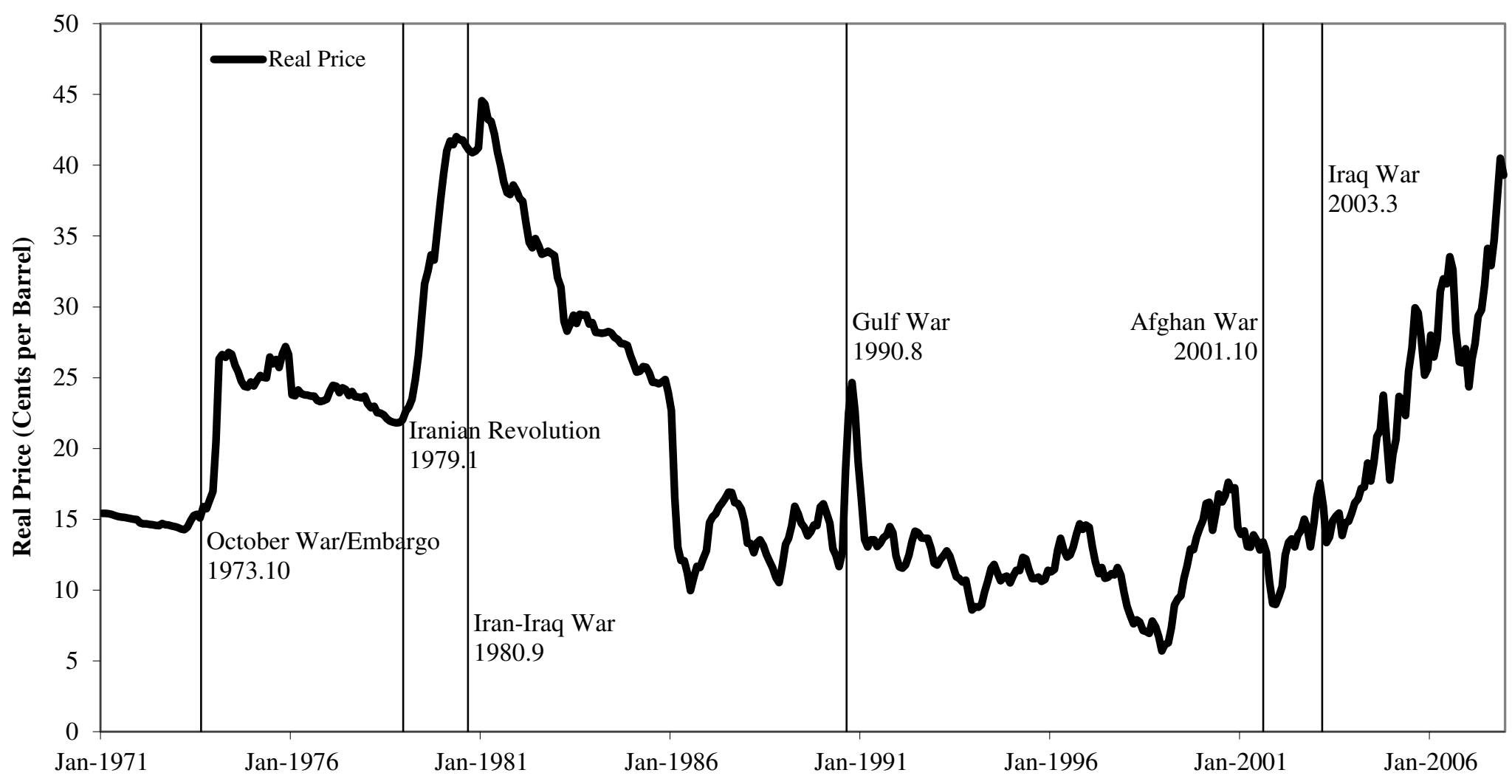

Notes: The oil price series is the refiner acquisition cost of imported crude oil as reported by the U.S. Department of Energy from 1974.1. The series is extended back to 1962.1 as in Barsky and Killian (2002) and Kilian (2007). The data period of the graph is 1971.1 to 2007.12 since there is not much movement in the extended series. The oil price is deflated by the U.S. CPI based on January 1983 dollars. 
Figure 2: The Monthly Growth Rate of Real Oil Price, 1971.1 - 2007.12

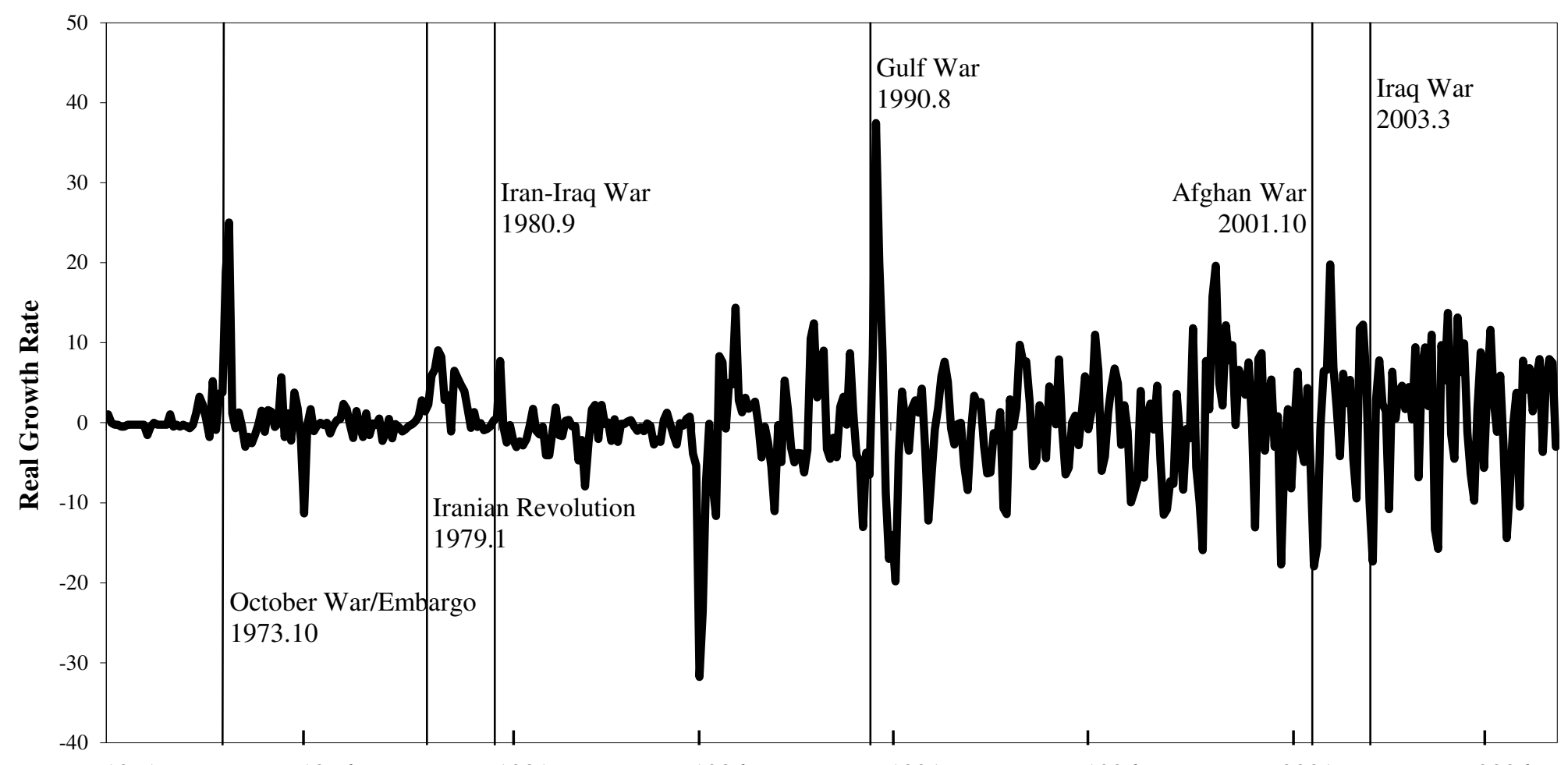

Jan-1971 Jan-1976 Jan-1981 Jan-1986 Jan-1991 Jan-1996 $\quad$ Jan-2001

Notes: The oil price series is the refiner acquisition cost of imported crude oil as reported by the U.S. Department of Energy from 1974.1. The series is extended back to 1962.1 as in Barsky and Killian (2002) and Kilian (2007). The data period of the graph is 1971.1 to 2007.12 since there is not much movement in the extended series. The oil price is deflated by the U.S. CPI based on January 1983 dollars. 
Figure 3: Monthly Volatility of S\&P 500 Index

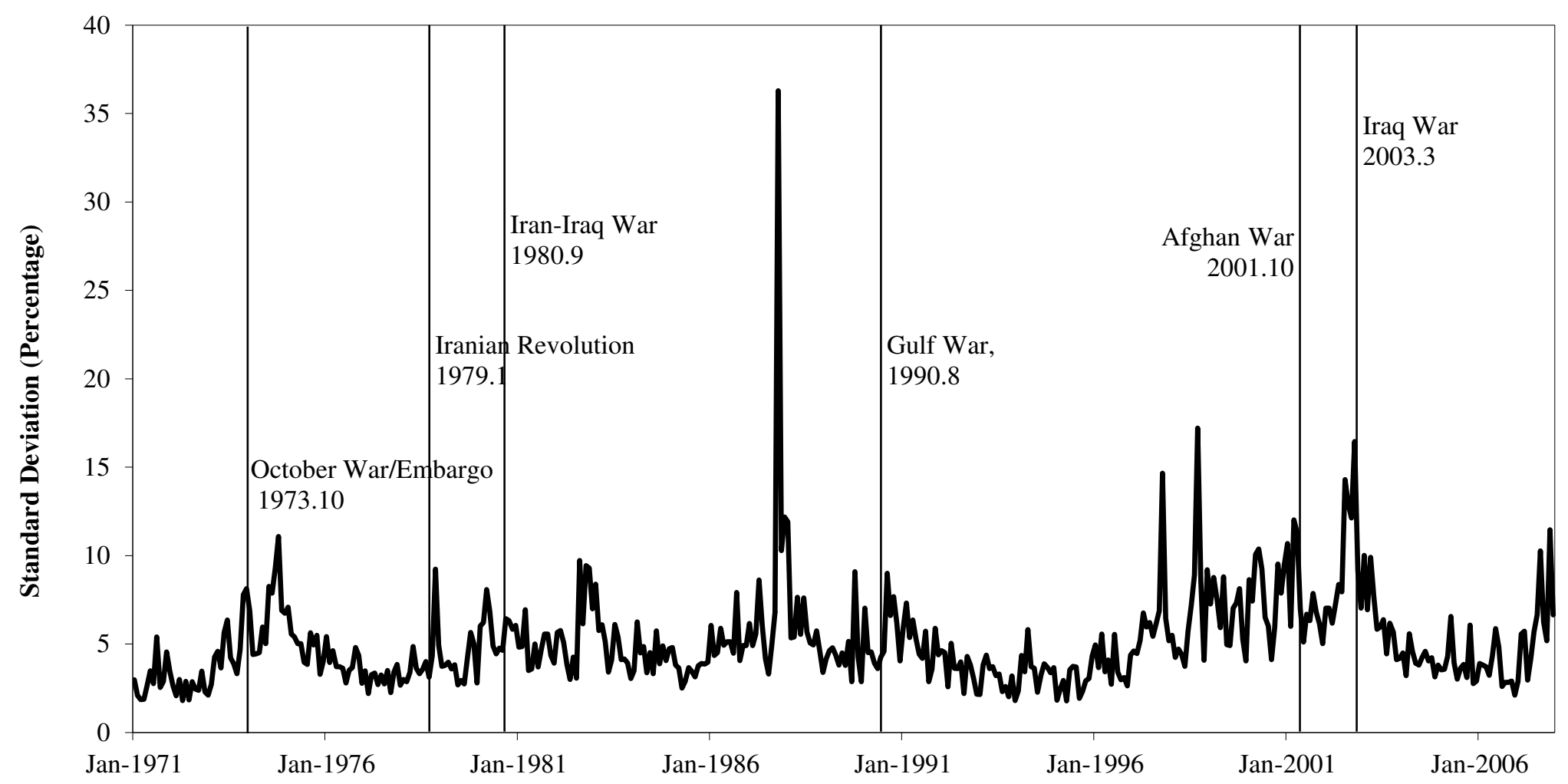

Notes: The monthly volatiltiy of S\&P 500 index is constructed using S\&P 500 daily index returns based on Baum et al.'s (2008) approach. The sample in the text is from January 1962 to December 2007. The graph shows the data period from 1971.1 to 2007.12. 
Figure 4: Oil Price Shock/Uncertainty $U(12)_{t}$

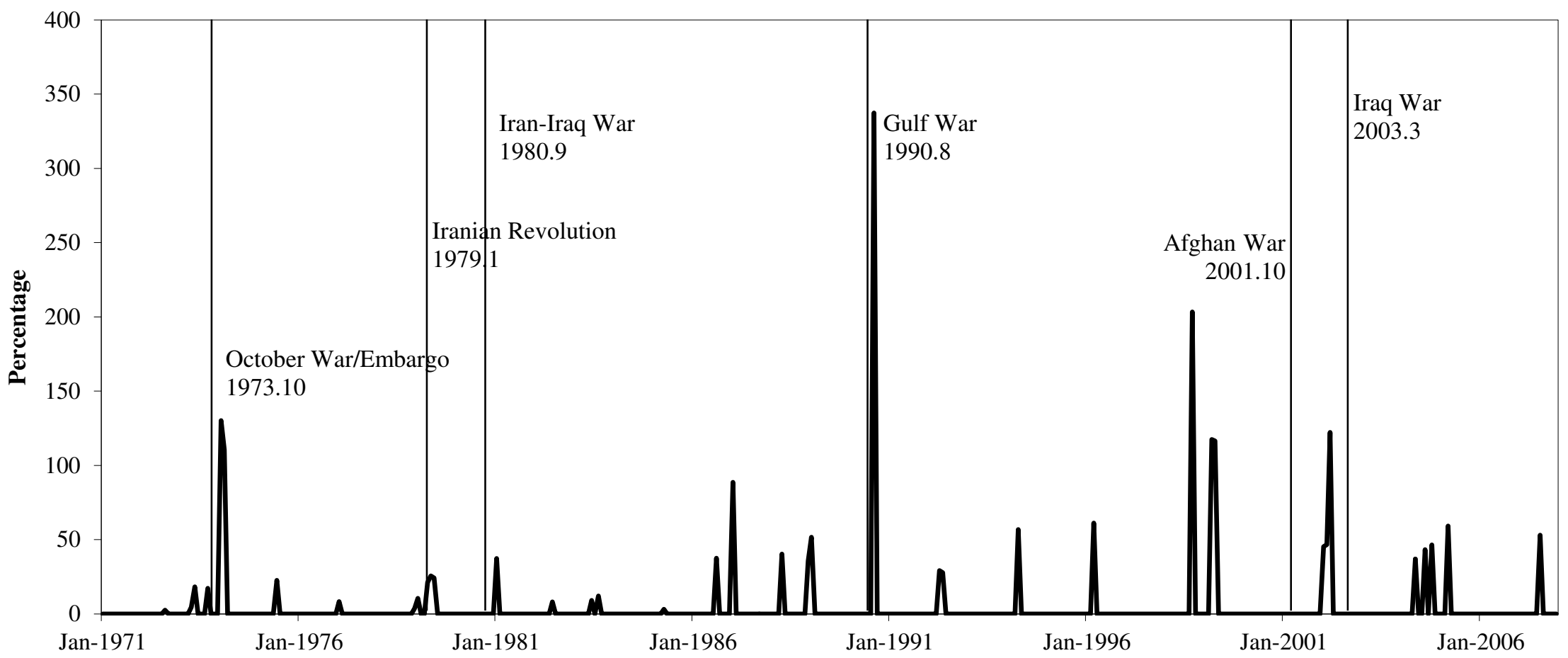

Notes: The monthly volatiltiy of S\&P 500 index is constructed using S\&P 500 daily index returns based on Baum et al.'s (2008) approach. The oil price shock/uncertainty $U(12)_{t}$ is equal to the product of monthly S\&P 500 standard deviation and oil price shock pgmax(12) that is set equal to the monthly real oil price growth rate, $p g_{t}$, if $p g_{t}$ is greater than the maximum of the last 12 months and 0 otherwise. The sample in the text is from January 1962 to December 2007. The graph shows the sample data from 1971.1 to 2007.12 . 
Figure 5: Oil Price Shock/Uncertainty $U(12)^{01}{ }_{t}$

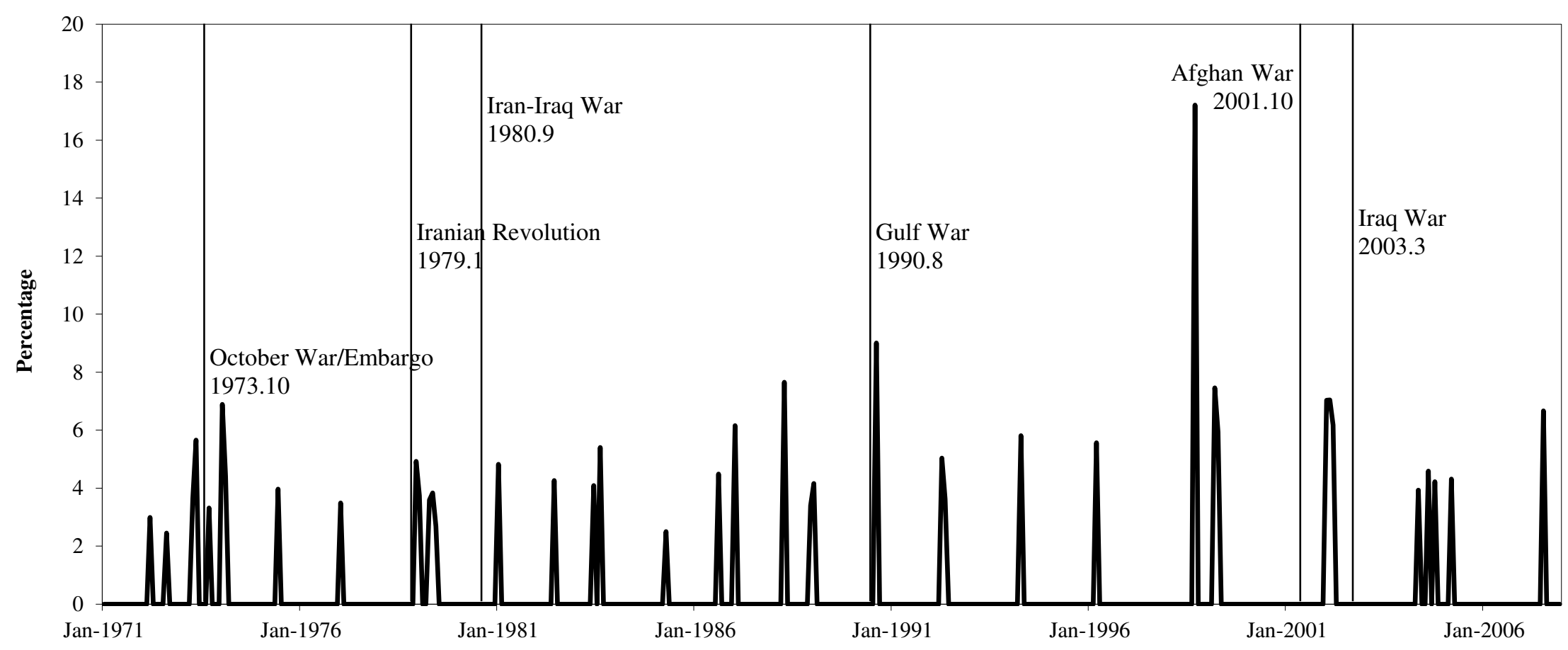

Notes: The monthly volatiltiy of S\&P 500 index is constructed using S\&P 500 daily index returns based on Baum et al.'s (2008) approach. The oil price shock/uncertainty $U(12)_{t}^{01}$ is equal to the product of monthly S\&P 500 standard deviation and an oil shock indicator function, pgmax(12) ${ }^{01}{ }_{t}$, that is 1 if the monthly real oil price growth rate, $p g_{t}$, is greater than the maximum of the last 12 months, 0 otherwise. The sample in the text is from January 1962 to December 2007. The graph shows the sample data from 1971.1 to 2007.12. 